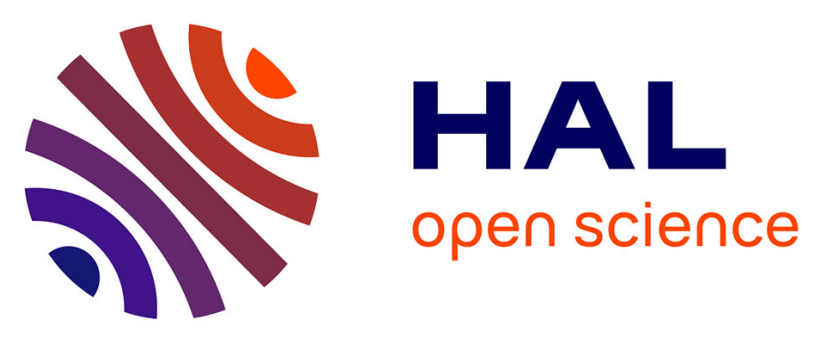

\title{
Seismic markers of the Messinian Salinity Crisis in an intermediate-depth basin: data for understanding the Neogene evolution of the Corsica Basin (Northern Tyrrhenian Sea)
}

Isabelle Thinon, Pol Guennoc, Olivier Serrano, Agnès Maillard, Eric Lasseur, Jean-Pierre Rehault

\section{To cite this version:}

Isabelle Thinon, Pol Guennoc, Olivier Serrano, Agnès Maillard, Eric Lasseur, et al.. Seismic markers of the Messinian Salinity Crisis in an intermediate-depth basin: data for understanding the Neogene evolution of the Corsica Basin (Northern Tyrrhenian Sea). Marine and Petroleum Geology, 2016, 77, pp.1274-1296. 10.1016/j.marpetgeo.2016.02.017 . hal-01336270

\section{HAL Id: hal-01336270 https: / hal-brgm.archives-ouvertes.fr/hal-01336270}

Submitted on 22 Jun 2016

HAL is a multi-disciplinary open access archive for the deposit and dissemination of scientific research documents, whether they are published or not. The documents may come from teaching and research institutions in France or abroad, or from public or private research centers.
L'archive ouverte pluridisciplinaire HAL, est destinée au dépôt et à la diffusion de documents scientifiques de niveau recherche, publiés ou non, émanant des établissements d'enseignement et de recherche français ou étrangers, des laboratoires publics ou privés. 
Thinon et al. In press 2016 - Seismic markers of the Messinian Salinity Crisis in an intermediate-depth basin: data for understanding the Neogene evolution of the Corsica Basin (Northern Tyrrhenian Sea) - Marine and Petroleum Geology

\title{
Seismic markers of the Messinian Salinity Crisis in an intermediate-depth basin: data for understanding the Neogene evolution of the Corsica Basin (Northern Tyrrhenian Sea)
}

\author{
Thinon I. (1), Guennoc P. (1), Serrano O. (1), Maillard A. ${ }^{(2)}$, Lasseur, E. (1), Réhault J.P. (3). \\ (1) BRGM - 3 avenue Claude Guillemin BP36009 45060 Orléans cédex 2. Email: \\ i.thinon@brgm.fr-tel.+33(0)2 386433 35; fax: +33 (0)2 386433 33; \\ (2) Observatoire Midi Pyrénées Imtg 14, avenue Edouard Belin 31400 Toulouse \\ (3) UBO, "domaines océaniques", place Nicolas Copernic, 29280 Plouzané Brest
}

\begin{abstract}
The Messinian Salinity Crisis (MSC), which widely affected the whole Mediterranean basin, induced rapid and spectacular palaeoenvironmental changes. It led to a major erosion of the onshore areas and the upper parts of the continental shelves and slopes, as well as important evaporitic deposits in the offshore deep basins. The Corsica Basin belongs to the so-called "intermediate-depth basin" type because of its location between the coastal plainshelf area of East Corsica and deeper marine basins in the northern Tyrrhenian Sea. The MSC event took place in the Corsica Basin during a period of active regional tectonics, contemporaneous with the opening of the Tyrrhenian Sea, as well as during the development of the Corsica Basin and the Elba-Pianosa Ridge.

Based on the interpretation of high-resolution seismic reflection profiles and a new 1:250,000 scale synthetic geological map, we establish that the MSC is recorded in the Corsica Basin through the occurrence of two sedimentary formations bounded by three remarkable surfaces. These seismic markers suggest local and temporal variations in relative water level and associated depositional environments that differ between the north and south of the Corsica Basin. During the MSC, the northern sector (Golo Basin) was emerged, whereas the southern sector (Orbo Basin) was often flooded or submerged. In the Orbo Basin, the deposits record both an episode of intra-MSC climate change and regional tectonic events. During the MSC, the Corsica Basin was a perched lake, isolated from the deeper Tyrrhenian basins. The connection with the Tyrrhenian basins was re-established during the final stages of the MSC, before the catastrophic Pliocene reflooding, initiated by retrogressive
\end{abstract}


erosion during a relative lowstand. An extensive network of incised valleys was thus established in the Orbo basin, allowing the drainage of the Corsica Basin southwards into the deeper Tyrrhenian basins. These markers record the active regional tectonic context throughout the MSC. The Orbo basin was strongly subsident along its western rim, while its eastern rim was uplifted. In turn, the Golo basin subsided from middle Pliocene times onwards, while the northern, eastern and southern edges of the Corsica Basin were deformed and uplifted.

\section{Keywords}

Messinian Salinity Crisis, syn-MSC deposits, Incision network, Corsica Basin, Tyrrhenian Sea, Pliocene reflooding.

\section{Abbreviations}

EPR $=$ Elba-Pianosa Ridge

$\mathrm{MSC}=$ Messinian Salinity Crisis

$F m=$ formation 
Thinon et al. In press 2016 - Seismic markers of the Messinian Salinity Crisis in an intermediate-depth basin: data for understanding the Neogene evolution of the Corsica Basin (Northern Tyrrhenian Sea) - Marine and Petroleum Geology

\section{INTRODUCTION}

The Messinian Salinity Crisis (MSC), which affected the whole Mediterranean area (Fig. 1) at the end of the Miocene between 5.97 and $5.33 \mathrm{Ma}$, induced rapid and spectacular palaeo-environmental changes (Hsü et al., 1973,Krijgsman et al., 1999,CIESM, 2008,Manzi et al., 2013,Roveri et al., 2014a)and references therein). The MSC came to an end when the Mediterranean Sea was reconnected to the Atlantic Ocean via the Gibraltar Strait at around 5.46 Ma (Bache et al., 2012)), leading to catastrophic reflooding at $5.33 \mathrm{Ma}$ (Roveri et al., 2014). The first stage (5.97-5.6 Ma) is mainly defined from onshore outcrops in the marginal or peripheral basins, where a thinner evaporite sequence has been recognized known as the Primary Lower Gypsum (PLG) (Riding et al., 1998,Roveri et al., 2009,Roveri et al., 2014b); Manzi et al., 2013 and references therein). The PLG is usually incised by a major erosion surface correlated with the Margin Erosion Surface (MES) (Roveri et al., 2014b) observed on the Mediterranean margins. The second (5.6-5.55 Ma) and third (5.55-5.33 Ma) stages (Roveri et al., 2014b,CIESM, 2008) are characterized by a continuing fall in sea-level, becoming maximal during the second stage, with subaerial erosion (MES) of the continental margins and coeval with the deposition of a thick evaporite sequence in the deep basins (up to 1,400 m thick, i.e. Montadert et al., 1970; (Montadert et al., 1970,Hsü et al., 1973,Krijgsman et al., 1999)This evaporite sequence is composed of three distinct seismic units, recently renamed the Upper Unit (UU), the Mobile Unit (MU) and the Lower Unit (LU) by Lofi et al. (2011). An ambiguity persists concerning the age of the end of the sea-level fall. Thus, the MSC deposits, described in terms of sequence stratigraphy by Gorini et al. (2015), have been divided into two seismic megasequences: i) a Messinian Lower Megasequence (MLM) coeval with the sea-level fall (5.97-5.55 Ma) includes forced regressive deltas, mass transport complexes, deep basin clastics and evaporites (LU). ii) a Messinian Upper Megasequence (MUM), coeval with an increase in base level (5.55-5.33 Ma), includes evaporite units (MU and UU), fluvial incised valley fill, transgressive marine sands and material reworked by the catastrophic reflooding. This stratigraphic pattern is effectively in accordance with the transgressive geometry of the UU (Ryan et al., 1973; Mauffret, 1976) and the age of $5.55 \mathrm{Ma}$ 
Thinon et al. In press 2016 - Seismic markers of the Messinian Salinity Crisis in an intermediate-depth basin: data for understanding the Neogene evolution of the Corsica Basin (Northern Tyrrhenian Sea) - Marine and Petroleum Geology

for the MSC paroxysmal phase (CIESM, 2008, Gorini et al., 2015 and references therein). Moreover, around 5.5 Ma ago, there were significant changes in the palaeogeography and climate of the Mediterranean region (Fauquette et al., 2006; Manzi et al., 2013; Roveri et al., 2014).

No continuous record of the MSC has been observed between the onshore marginal basins and offshore deep basins. However, owing to their specific paleodepths at the onset of the MSC (between 200 and $1000 \mathrm{~m}$ ), the intermediate-depth basins (Maillard et al. 2014, Ochoa et al., 2015) may provide important information on events and sea-level fluctuations during the MSC. Intermediate-depth basins have been defined as more or less restricted areas, corresponding to intermittent or thin depocentres located between the shallow platform and the continental slope. These areas were subject to strong erosion during the MSC on one side, while thick evaporitic sequences were deposited in deep basins on the other side. In some intermediate-depth basins, an important seismic unit, known as the Bedded Unit (BU; Lofi et al., 2011), has also been identified, as in the corsican basins (Guennoc et al., 2011,Thinon et al., 2011) and in the Balearic Promontory (Maillard et al., 2014,Ochoa et al., 2015). In the Balearic promontory, but only in the onshore coastal and shallow water areas, the BU has been interpreted as an "offshore expression of the PLG" sequence below the MES (Ochoa et al., 2015). From Gorini et al. (2015), the BU units are coeval with MUM deposition in the deep basin, post-dating the rapid draining of the intermediate-depth basin.

In addition to the MSC seismic units, some remarkable surfaces are also markers of the MSC. Clearly identified on all Mediterranean margins, the MES is expressed as a single, generalized and polygenic erosional surface (Bache et al., 2010,Lofi et al., 2005,Maillard and Mauffret, 2006, Lofi et al., 2011). At the foot of the Mediterranean margins, the MES divides laterally into at least two remarkable surfaces: 1) Bottom Erosion Surface (BES, Lofi et al., 2011) is considered to be the bounding erosive surface marking the base of the syn-MSC deposits; 2) Top Erosion Surface (TES), which corresponds to the bounding surface marking the top of the syn-MSC deposits, characterized by major incisions. 
Thinon et al. In press 2016 - Seismic markers of the Messinian Salinity Crisis in an intermediate-depth basin: data for understanding the Neogene evolution of the Corsica Basin (Northern Tyrrhenian Sea) - Marine and Petroleum Geology

This study focuses on the interaction between MSC markers and the Neogene evolution of the Corsica Basin. The Corsica Basin is an intermediate-depth basin, which formed in a shelf environment during the pre-MSC Miocene (Fig. 1, Fig. 2). Our study is based on mapping of the various syn-MSC seismic units and surfaces, as well as on an analysis of their seismic facies and spatial distributions. Owing to the MSC markers, post-MSC vertical motions can be highlighted and an evolution can be proposed for the Corsica Basin since the end of the Miocene.

\section{REgionAL SETtING AND STATE OF KNOWLEDGE}

\subsection{Present-day physiography}

Corsica is classically divided into two main geological domains (Fig. 2): Hercynian Corsica, which extends southwards into Sardinia, and Alpine Corsica, which makes up the southern extension of the western Alps. These two domains abut along a major tectonic contact striking NNW-SSE from Ile Rousse to Solenzara passing through Corte. Onshore, the Eastern Corsica coastal area is characterized by alternating rugged relief and elongated plains such as the Bastia and Aleria plains (Caron et al., 1990b,Janzein et al., 1982). Offshore, the East-Corsican margin (Fig. 1b) is marked by a relatively broad (ca. $10 \mathrm{~km}$ ) continental shelf which narrows considerably north of Bastia and south of Solenzara (ca. $2 \mathrm{~km})$. Inversely, the shelf area widens at both ends, north of Cap Corse and east of the Bonifacio Straits. The Caprera Canyon, the largest canyon of the eastern Corsica-Sardinia margin, cuts the north-Sardinian continental shelf following a NE-SW trend.

The narrow continental slope is incised by numerous canyons which convey detrital materials supplied by the rivers of eastern Corsica. These materials are discharged and confined into the deeper Corsica Basin, where they form turbidite systems (Bellaiche et al., 1993,Gervais et al., 2004,Gervais et al., 2006b,Gervais et al., 2006a,Calvès et al., 2012,Stanley et al., 1980).

To the east, the Corsica Basin lies between the East-Corsica margin, the Tuscan shelf (where the MSC is recorded by the MES) and the North Tyrrhenian Sea deep basins, in which Messinian evaporite units have been described (Moussat, 1983,Gaullier et al., 2014). The 
Thinon et al. In press 2016 - Seismic markers of the Messinian Salinity Crisis in an intermediate-depth basin: data for understanding the Neogene evolution of the Corsica Basin (Northern Tyrrhenian Sea) - Marine and Petroleum Geology

Corsica Basin is separated from the Tuscan Shelf by the Elba-Pianosa Ridge (EPR), which is a N-S elongated submarine structural/morphological high dotted with islands (Capraia, Elba, Pianosa, Montecristo, Scoglio d'Affrica, etc.). The Corsica Basin is narrow (30 km wide by $190 \mathrm{~km}$ long) and strikes according to a NNE-SSW axis, with a present-day water depth of $400 \mathrm{~m}$ at the northern end and more than $900 \mathrm{~m}$ in the south. It is divided into two sub-basins at $42^{\circ} \mathrm{N}$ latitude, called the Golo Basin and the Orbo Basin. The Golo and Fium Alto rivers discharge into the former, whereas the Tavignano and Fium Orbo rivers discharge into the latter. The present-day transition between the Corsica Basin (max depth more than $900 \mathrm{~m}$ ) and the deep evaporitic Tyrrhenian basins is characterized by a steep slope (about $1.3^{\circ}$ ).

\subsection{Regional geodynamic evolution, structure of the Corsica Basin and the East Pianosa Ridge}

From the Oligocene to Present, the eastward retreat of the Calabria-Apennine subduction (Jolivet et al., 2006,Argnani, 2012) led to the $30^{\circ}$ counterclockwise rotation of the Corsica-Sardinia block during the Aquitanian-Burdigalian and oceanic opening of the LiguriaProvençal Basin (Gueguen et al., 1998,Speranza et al., 2002,Gattacceca et al., 2007). This was followed in the Tortonian-Messinian by back-arc rifting of the Tyrrhenian Sea, and then oceanic accretion dated between around $8 \mathrm{Ma}$ and $4 \mathrm{Ma}$ (Kastens and Mascle, 1990,Argnani, 2012,Dewey et al., 1989,Faccenna et al., 1997,Brunet et al., 2000,Dini et al., 2002). From the Early Eocene up to the Early Miocene, the domain to the east of Corsica consisted of a wide and complex sedimentary basin system known as the EPR-proto Corsica Basin system (Fig. 3, Cornamusini and Pascucci, 2014). From Late Burdigalian to Langhian times, the Corsica Basin developed as a N-S-trending basin that underwent major subsidence. During the Late Serravallian and Tortonian, the subsidence axis shifted eastwards onto the Tuscan Shelf (Bartole, 1995,Pascucci et al., 1999). In the Tyrrhenian basin, extension developed from the Late Oligocene (e.g. Réhault et al., 1987) or from the Miocene to Present (Malinverno and Ryan, 1986). Tortonian syn-rift deposits of the Sardinian margin mark the initial stage of the Tyrrhenian rifting process (Dogliani et al., 1994; Facenna et al., 1997; Cocchi et al., in press). The tectonic extension evolved to accretion of oceanic crust in two areas of the southeastern Tyrrhenian Sea, the Vavilov basin (7-3.5 Ma, Bigi et al., 1989; 4.3-2.6 Ma, Kastens et al., 
Thinon et al. In press 2016 - Seismic markers of the Messinian Salinity Crisis in an intermediate-depth basin: data for understanding the Neogene evolution of the Corsica Basin (Northern Tyrrhenian Sea) - Marine and Petroleum Geology

1990; or 8-4 Ma, Facenna et al., 2007) and the Marsili basin (1.7-1.2 Ma) (Bigi et al., 1989; Pascucci, 2002; Greve et al., 2014; (Pascucci, 2002,Prada et al., 2014).The extension axis was mainly W-E during the Tortonian ( 11 Ma; Zitellini et al., 1986; Kastens et al., 1990), but became re-oriented NW-SE in the southeastern part from the Late Pliocene ( 2 Ma according to Kastens et al., 1990). However, during the MSC, the structural pattern of the western Tyrrhenian basin was controlled by a system of N-S ridges, such as the Baronie seamount (Gaullier et al., 2014).

The Corsica Basin is the oldest, the largest and also the deepest basin of the Tuscan domain (Gabin, 1972,Aleria, 1979,Viaris de Lesegno et al., 1978). The underlying continental crust is as thin as (Contrucci, 1999,Mauffret et al., 1999), whereas it becomes thicker beneath Corsica (Hirn and Sapin, 1976) and under the EPR (between 20 and 26 km, Contrucci, 1999; (Mele and Sandvol, 2003,Carminati and Doglioni, 2012). The Corsica Basin is filled with a sedimentary succession which is up to $8 \mathrm{~km}$ thick as inferred from seismic data, ranging in age from Eocene to Pleistocene (Contrucci, 1999,Contrucci et al., 2005,Mauffret et al., 1999,Pascucci, 2002,Finetti et al., 2005). The sedimentary filling of the proto-Corsica Basin appears similar to the EPR Tertiary sedimentary successions (Cornamusini and Pascucci, 2014). The Corsica Basin is an asymmetrical sedimentary basin bounded by the St-Antoine and Solenzara Faults to the west, at the contact between the Neogene Aleria Plain and the Hercynian or Alpine basement (Fig. 1 to Fig. 3) (Contrucci et al., 2005,Mauffret et al., 1999,Gabin, 1972). A large vertical displacement is assumed along the NE-SW-striking StAntoine Fault, with at least $4 \mathrm{~km}$ of throw (Finetti et al., 2005) and a left-lateral strike slip (Serrano et al., 2013,Loÿe-Pilot et al., 2004)The NW-SE-striking Solenzara Fault is composed of steep normal faults (dips $>60^{\circ} \mathrm{NE}$ ) with right-lateral strike slip component (Serrano et al., 2013,Loÿe-Pilot et al., 2004)According to analysis of magnetic and gravity anomalies, the Solenzara Fault probably extends to the south-east as far as the deep basins of the Tyrrhenian Sea (Mauffret et al., 1999,Finetti et al., 2005). This major structure would represent the tectonic front of the Corsican Alps (Finetti et al., 2005). The Solenzara Fault appears to have been active from the Aquitanian (23-20 Ma) (Carmignani et al., 1995,Pasci, 1997) or 
Thinon et al. In press 2016 - Seismic markers of the Messinian Salinity Crisis in an intermediate-depth basin: data for understanding the Neogene evolution of the Corsica Basin (Northern Tyrrhenian Sea) - Marine and Petroleum Geology

the Burdigalian (20 - $16 \mathrm{Ma}$ ) (Letouzey et al., 1982,Cherchi and Trémolières, 1984)up until the Quaternary (Caron et al., 1990a,Janzein et al., 1982,Serrano et al., 2013). Starting in the Late Pliocene, subsidence increased in the northern part of the Neogene Aleria Plain, synchronously with major subsidence as observed in the Bastia Plain (Caron et al., 1990b). The Pliocene and Quaternary sedimentary formations are affected by weak deformation, characterized by normal faults with uplift or tilting axes striking NW-SE ((Caron et al., 1990a,Janzein et al., 1982,Serrano et al., 2013). During the Quaternary, some alluvial terraces were uplifted and tilted, and some rivers were modified (Serrano et al., 2013).

The EPR developed both as a result of the Middle-Late Burdigalian-Langhian tectonic event and the Miocene magmatism (Finetti et al., 2001,Cornamusini et al., 2014). Thus, this $\mathrm{N}$-S-trending ridge is also characterized by the occurrence of several granite plutons and volcanic massifs. The magmatic complex of Elba Island (8.4-5.9 ma), including the Monte Capanne batholith (6.8-6.2 Ma) and laccolith/vein system (Serri et al., 2001; Dini et al., 2002; Peccerillo, 2003; Westerman et al., 2004), as well as Montecristo Island (7.3-7.1 Ma) and the volcanism of Capraia Island (about $7 \mathrm{Ma}$ ), all date from the late Tortonian-Messinian up to the Early Pliocene (Serri et al., 2001; Peccerillo, 2003 with references therein). The build-up of the EPR probably culminated in emergence and resulted in a late Burdigalian?-Langhian erosional phase (Carmignani et al., 1995,Cornamusini et al., 2002,Contrucci, 1999,Contrucci et al., 2005,Bartole, 1995,Cornamusini and Pascucci, 2014,Cornamusini and Pascucci, 2014,Cornamusini et al., 2014)). During Tortonian-Messinian times, the development of the Corsica-Tuscan Shelf rift basin system was related to a major phase of opening of the Tyrrhenian Sea, which resulted in the widening and emergence of the EPR (Cornamusini et al., 2014). These authors (op.cit.) show that the continuous uplift and dismantling of the EPR induced a well-developed drainage system flowing both westwards (Corsica Basin) and eastwards (Tuscan Shelf). The uplift of the EPR continued into the Middle Pliocene (Contrucci, 1999) and up to the Present (Gervais et al., 2006a,Gabin, 1972). Since the Miocene, the development of the EPR tended to isolate the Corsica Basin from the Tuscan shelf to the East and from the Tyrrhenian basins to the South. 
Thinon et al. In press 2016 - Seismic markers of the Messinian Salinity Crisis in an intermediate-depth basin: data for understanding the Neogene evolution of the Corsica Basin (Northern Tyrrhenian Sea) - Marine and Petroleum Geology

\subsection{Cenozoic sedimentary cover}

\subsubsection{Pre-MSC Miocene formations}

The Pre-MSC sedimentary cover of the Corsica Basin is composed of Miocene deposits of Aquitanian to Late Messinian age (Aleria, 1979,Viaris de Lesegno, 1978,Viaris de Lesegno et al., 1978) overlying a thick Eocene/Oligocene succession (Cornamusini and Pascucci, 2014). The basement of the Corsica basin reaches a depth of $8.5 \mathrm{~km}$ (Mauffret et al., 1999,Contrucci, 1999,Contrucci et al., 2005). The Neogene Pre-MSC Miocene formations, outcropping onshore around the Corsica Basin, suggest a well-developed shallow depositional environment. Finetti et al. (2001) propose that the main deepening of the Corsica Basin occurred between the Miocene and the Quaternary (8-1 Ma), contemporaneously with the opening of the Tyrrhenian Sea.

Neogene pre-MSC Miocene formations (Fig. 4a) outcrop extensively on the Aleria Plain, which is the western onshore part of the Corsica Basin (Orszag-Sperber and Pilot, 1976,Caron et al., 1990b,Serrano et al., 2013,Orszag-Sperber et al., 2000,Janzein et al., 1982,Loÿe-Pilot et al., 2004,Loÿe-Pilot and Ferrandini, 2014)These formations of the Aleria Plain appear to consist of a thick $(1-2 \mathrm{~km})$ sequence dating from the Middle Burdigalian to the Messinian, including Serravallian and Tortonian units, deposited in a shallow marine to coastal environment. A sedimentary hiatus presumably marks the post-Langhian emergence (Orszag-Sperber and Pilot, 1976,Brunet et al., 2000,Serrano et al., 2013)(Orszag-Sperber and Pilot, 1976; Brunet et al., 2000; Fig. 4a). The Miocene deposits are composed of detrital materials derived from Alpine units, but only since the early Tortonian, while the older clastic deposits are mainly sourced from Hercynian granitoids (Loÿe-Pilot and Magné, 1978; Bossio et al. 2000; Loÿe-Pilot et al., 2004; Loÿe-Pilot and Ferrandini, 2014). This change in the detrital source is explained by the exhumation of Alpine Corsica dated as Early-Middle Miocene (Zarki-Jakni et al., 2004; Fellin et al., 2005; Cavazza et al., 2007). The oldest preMSC formations, which crop out on the Aleria Plain, make up the Burdigalian St-Antoine Fm and Alzelle Fm (Fig. 4a) (Loÿe-Pilot and Magné, 1978; Loÿe-Pilot et al., 2004; Serrano et al., 2013; Loÿe-Pilot and Ferrandini, 2014). The Burdigalian-Langhian Aghione Fm is composed 
Thinon et al. In press 2016 - Seismic markers of the Messinian Salinity Crisis in an intermediate-depth basin: data for understanding the Neogene evolution of the Corsica Basin (Northern Tyrrhenian Sea) - Marine and Petroleum Geology

of sandstones and conglomerates with rhyolitic pebbles and marls rich in microfauna, which indicate a marine environment undergoing rapid subsidence (Loÿe-Pilot and Ferrandini, 2014). It is coeval with the Marina del Marchese Fm of the EPR, according to Cornamusini and Pascucci (2014) (Fig. 4b). The Aghione Fm passes up gradually into the Alzitone Fm, which is attributed to the Serravalian. The Alzitone Fm consists of poorly sorted heterogranular sandstones with numerous fluvial channelized rhyolitic conglomerates, which are capped by sub-aerial sandy facies and paleosoils marking a possible hiatus at the Serravalian/Tortonian boundary. The basal Tortonian is represented by the shallow marine Vadina Fm characterized by alternations of massive fine-grained sandstones, organogenic reefal limestones and conglomeratic levels. This formation is capped by a hiatus overlain by the Casabianda Fm of Upper Tortonian to basal Messinian age, which is composed of sandy marls with sand lenses, intercalations of fossiliferous sandy and muddy limestones.

The pre-MSC formations of the EPR consist of Miocene sedimentary deposits overlying Upper Oligocene and Eocene formations, in turn lying unconformably on deformed Helminthoid flysch of Cretaceous-Paleocene age (Heezen et al., 1971; Viaris de Lesegno et al., 1978; Carmignani et al., 1994, 2004; Bartole, 1995; Contrucci, 1999; Pascucci et al., 1999; Brunet et al., 2000; Cornamusini et al., 2002; Cornamusini and Pascucci, 2014). During the Eocene-Oligocene, the EPR-proto-Corsica Basin system is characterized by the development of mainly siliciclastic turbidite fans, deposited in bathyal to outer neritic environments. However, during the Burdigalian, this system is characterized by outer-shelf calciturbidites (Fig. 4b, Marina del Marchese Fm) whose basinal depocentre appears to be located close to the Solenzara Fault (Fig. 3) (Cornamusini and Pascucci, 2014). During the Late Tortonian, the fluvio-lacustrine depositional environment developed close to the EPR shifted towards a marine/littoral conditions during the Early Messinian up until the MSC (Cornamusini et al., 2014). According to Carmignani et al. (2004), the basins of the Tuscan Shelf are filled with a Middle Miocene to Quaternary sedimentary succession overlying the orogenic substratum. During late Messinian times, the evaporites and continental facies of the Lago-Mare Unit were 
Thinon et al. In press 2016 - Seismic markers of the Messinian Salinity Crisis in an intermediate-depth basin: data for understanding the Neogene evolution of the Corsica Basin (Northern Tyrrhenian Sea) - Marine and Petroleum Geology

deposited, showing evidence of a Paratethyan influence (laccarino and Bossio, 1999; Carmignani et al., 2004 and references therein).

While the present-day maximum water depth in the Corsica Basin is about $900 \mathrm{~m}$, the depth was shallower during the Messinian, being typical of shelf conditions (less than $200 \mathrm{~m}$ water depth) in view of the nature of the pre-MSC Miocene formations of the Neogene Aleria Plain (e.g. Serrano et al., 2013) and the EPR (Carmignani et al., 1994, 2004; Cornamusini and Pascucci, 2014; Cornamusini et al., 2014).

\subsubsection{Syn-MSC Messinian formations}

Rare syn-MSC formations have been sampled in the Tyrrhenian region, whereas they crop out extensively in onland Tuscany (Bossio et al., 1998; 2000). According to Aleria (1979), accumulation of sulphate or carbonate sediment types only occurred in the shallow zones during the Messinian, while evaporitic formations were deposited in the deep zones. Samples of an algal limestone associated with grey-green clays containing Cipridis pannonica (BG7820) and a mealy-white micrite (BS77-2) have been collected off the north-east Sardinian margin and in the Bonifacio Strait (Fig. 5). These samples have been assigned to the MSC evaporite sequence (Aleria, 1979). Dredges in the northern Corsica Basin and on the EPR to the west of the island of Gorgona have sampled some end-Miocene sediments, indicating a Lago-Mare-type environment according to Taviani et al. (2007). In the deep Tyrrhenian basins, only Hole 132 of DSDP Leg13 (Ryan et al., 1973) and Hole 373 of Leg42 (Hsü et al., 1978) have sampled gypsum of Late Miocene age. These samples are correlated with the Upper unit (UU) and Middle unit (MU) (Ryan et al., 1973; Moussat, 1983; Gaullier et al., 2009, 2014).

On the Aleria Plain, the syn-MSC deposits correspond to the Aleria Fm, which are then covered by the Lower Pliocene (Fig. 4a) (Saint Martin et al., 2007). The Aleria Fm is composed of sandy marls, sands and conglomerates with marl lenses containing Congeria and diatoms. The age of this formation is very controversial, with attributions ranging from Lower Pliocene to basal Messinian (Ottmann, 1958; Magné et al., 1975; Orszag-Sperber, 1978; Caron et al., 1990b; Saint Martin et al., 2007; Loÿe-Pilot and Ferrandini, 2014). The 
Thinon et al. In press 2016 - Seismic markers of the Messinian Salinity Crisis in an intermediate-depth basin: data for understanding the Neogene evolution of the Corsica Basin (Northern Tyrrhenian Sea) - Marine and Petroleum Geology

Aleria Fm is interpreted as representing fluviatile deposits (Ottmann, 1958; Orszag-Sperber, 1978; Ferrandini et al., 2004), described as a complex fluvio-deltaic system at the outlet of the present-day Tavignano river (Ottmann, 1958; Orszag-Sperber, 1978), or alternatively as a fluvial system with channels subject to frequent overflow (Ferrandini et al., 2004).

Based on its sedimentary and biological components, but also on its stratigraphic position, the Aleria Fm has been compared with the Lago-Mare deposits (Bossio et al., 2000; Orszag-Sperber et al., 2000; Loÿe-Pilot and Ferrandini, 2014). The observations of Serrano et al. (2013) show that this formation was laid down on a major discontinuity surface (Fig. 4) since the Aleria Fm rests locally on the Vadina Fm (lower Tortonian) and truncates the Casabianda Fm (Tortonian - lower Messinian). We attribute this major surface to the MES. Consequently, the Aleria Fm could correspond to syn-MSC deposits, but its preservation could also occur due to the regional reflooding.

In the offshore Corsica Basin, the deposits ascribed to the syn-MSC formation were defined during the 1970 s exclusively on the basis of seismic profiles, and referred to as the "Messinian Fm" (Fig. 6, Viaris de Lesegno et al., 1978; Aleria, 1979). This unit is located between the pre-MSC seismic units and the Plio-Quaternary (PQ) seismic units. The upper limit of this "Messinian Fm" was described as a major incision surface filled up by an extensive channeled system (Viaris de Lesegno et al., 1978). This discontinuity was named the Messinian surface, within the initial definition of the "M surface" (Ryan et al., 1973). The Messinian Fm was interpreted as being formed of endorheic (Aleria, 1979) or lacustrine deposits (Viaris de Lesegno et al., 1978).

\subsubsection{Pliocene Formations}

The Lower Pliocene deposits of the Aleria Plain, dated by abundant microfauna (Magné et al., 1975), are composed of clearly marine sandy marls (Urbino Fm.). This formation is coeval with the Pliocene reflooding interval dated at 5.46-5.33 Ma (e.g. Bache et al., 2012; Roveri et al., 2014) (see R on Fig. 4). According to Serrano et al. (2013), the marine regression at the end of the Early Pliocene induced a Middle Pliocene hiatus and the end of marine incursions. The Upper Pliocene unit (Peri Fm, Fig. 4a) is a continental formation 
Thinon et al. In press 2016 - Seismic markers of the Messinian Salinity Crisis in an intermediate-depth basin: data for understanding the Neogene evolution of the Corsica Basin (Northern Tyrrhenian Sea) - Marine and Petroleum Geology

composed of conglomerates interbedded with sand and clay layers with paleosols (Loÿe-Pilot and Magné, 1978; Serrano et al., 2013). It lies unconfomably on older formations (Fig. 4).

On the EPR, the substratum is often unconformably overlain by Pleistocene sediments and Pliocene deposits are absent (Bartole, 1995; Pascucci et al., 1999; Cornamusini et al., 2002; Cornamusini and Pascucci, 2014). In the Corsica Basin, a majority of authors (OrszagSperber and Pilot, 1976; Loÿe-Pilot et al., 2004; Serrano et al., 2013; Loÿe-Pilot and Ferrandini, 2014) suggest that the Lower Pliocene pelagic sedimentation gave way to active terrigenous inputs during the Middle Pliocene.

\section{DATA AND METHODS}

The available dataset (Fig. 6) includes old low-resolution seismic reflection profiles (e.g. MESIM, LISA, BacinoCorse cruises), provided by a variety of Universities and Institutes, as well as oil industry companies. In addition, around $7100 \mathrm{~km}$ of high-resolution seismic reflection profiles (HR) were acquired between 1997 and 2003 during training-course cruises of the University of Western Brittany (Corstage 97, 98, 99, 00 \& 01 cruises) and cruises of the Géosciences Azur laboratory (HR02D cruise) in collaboration with the French Geological Survey (BRGM). Two acquisition systems have been used to collect the HR seismic data: an airgun source with an AMG two-channel streamer and a sparker source (1000J) with a sixchannel streamer. The Very High-Resolution (VHR) seismic reflection profiles (LIMA1\&2, Bocca99, Bocca00, Geocorse2003 cruises) were acquired on the eastern Corsica continental shelf within the framework of collaborations between BRGM and the University of Corsica (M. Ferrandini). The acquisition tools consisted of a sparker source (100-1000J power range) with either a single or a six-channel streamer. The acquisition parameters of these HR and VHR cruises are specified on the European GEO-seas website (http://www.geo-seas.net). Interpretation of the seismic data was performed with the Seisvision-Geographix® software. The designation of the units and surfaces associated with the MSC is based on the nomenclature of the Mediterranean Messinian seismic markers established by Lofi et al. (2011) and correlated to the Messinian sequential stratigraphy defined by Gorini et al. (2015). 
Thinon et al. In press 2016 - Seismic markers of the Messinian Salinity Crisis in an intermediate-depth basin: data for understanding the Neogene evolution of the Corsica Basin (Northern Tyrrhenian Sea) - Marine and Petroleum Geology

The density of the seismic profiles and data output from the interpretations has enabled a 3D geometric model to be established for the southern sector of the Corsica Basin by means of GeoModeller Software (Calcagno et al., 2006). The isopach and isobath maps presented in the present study are derived from the 3D geologic modelling (in depth) of the southern Corsica Basin (Calcagno et al., 2004).

Investigations conducted over the decade since 2000 have allowed us to identify the MSC seismic markers and describe the distribution, geometry and facies changes of the synMSC "Messinian Fm". From this study, we propose a model for the geological evolution of the Corsica Basin during the MSC and early post-MSC times.

\section{MAIN RESULtS}

The interpretation of the numerous HR seismic reflection profiles (Fig. 5, Fig. 7) has allowed us to establish a detailed and precise spatial distribution of the syn-MSC Messinian markers. Moreover, various maps have been drawn up, such as a geological map of the prePliocene formations of eastern Corsica and the network of syn-MSC incisions (Fig. 8), as well as isopach maps of the syn-MSC Messinian and the Plio-Quaternary formations (Fig. 9, Fig. 10) of the Corsica Basin. The syn-MSC Messinian markers are also used to quantify the postMSC vertical motions and understand the post-Miocene evolution of the Corsica Basin.

\subsection{Pre-MSC seismic units}

Two pre-MSC Miocene formations can be identified: an acoustic basement and a preMSC seismic unit, sometimes cropping out under a fine sedimentary cover on the shelf (Fig. 11 to Fig. 17).

The seismic facies of the acoustic basement is non-reflective. Its top is a diffracting and relatively continuous reflector. Mapping (Fig. 8) shows that offshore Bonifacio, the continental shelf acoustic basement coincides with the extension of the granitic bodies of Corsica and the Sardinia Massif. Likewise, the Alpine Basement Units probably extend offshore, between the continental shelves of Bastia and Aleria, as well as along the coast off Cap Corse. 
Thinon et al. In press 2016 - Seismic markers of the Messinian Salinity Crisis in an intermediate-depth basin: data for understanding the Neogene evolution of the Corsica Basin (Northern Tyrrhenian Sea) - Marine and Petroleum Geology

The pre-MSC seismic unit on the THR seismic profiles across the Corsica continental shelf is characterized by a uniform acoustic facies made up of a succession of strong amplitude/low frequency reflectors that are concordant and continuous (Fig. 11, Fig. 12). In the Bonifacio Strait, this unit shows several sequences having distinct seismic facies (Reynaud et al., 2013). The pre-MSC seismic unit onlaps directly onto the acoustic basement, and is truncated by a major unconformity ascribed to the MSC and incised by canyons on the continental shelf as well as on the slope (Fig. 11b). In the Corsica Basin, the seismic facies of the pre-MSC unit is characterized by discontinuous, sub-horizontal, relatively weak-amplitude and low-frequency reflectors (Fig. 11, Fig. 13, Fig. 14). Its top coincides with the BES and its base is not observable using the HR seismic data in the present study. Burdigalian to Early Messinian formations also appear to be present within the pre-MSC of the Aleria continental shelf as an extension of the Neogene Aleria Plain.

Mapping shows (Fig. 8) that the pre-MSC Miocene units cropping out on the Corsica continental shelf are small in extent, being observed only in the Bonifacio Strait, on the shelf offshore from the Aleria Plain and to a minor degree along the coast of Cap Corse (Fig. 7b, Fig. 8). Elsewhere, the pre-MSC Miocene is not exposed at outcrop, either because it was eroded and/or covered by Plio-Quaternary formations or because it has undergone substantial downthrow along the major escarpments. On the Bastia continental shelf, the MES and the pre-MSC basement are not observed on the seismic profiles. Indeed, the building up of the shelf would be recent in this area, taking place during the Pliocene and Quaternary.

\subsection{Syn-MSC seismic markers}

Based on the HR seismic data, the Messinian Fm, initially defined by Aleria (1979) (Fig. 6), is placed between the PQ seismic units assigned to the Plio-Quaternary and the pre-MSC seismic units. The Messinian Fm is composed of two seismic units designated $\mathrm{BU}_{1}$ and $\mathrm{BU}_{2}$ (Fig. 7 to Fig. 17). Four specific surfaces are identified, attributed to the MES, BES, TES and Intermediate Erosion Surface (IES), which are assigned to the MSC. 
Thinon et al. In press 2016 - Seismic markers of the Messinian Salinity Crisis in an intermediate-depth basin: data for understanding the Neogene evolution of the Corsica Basin (Northern Tyrrhenian Sea) - Marine and Petroleum Geology

\subsubsection{Syn-MSC remarkable surfaces}

The Margin Erosion Surface (MES) is observed on the East-Corsica margin, the EPR and the northern part (Golo Basin) of the Corsica Basin (Fig. 8). The MES is a seismic horizon with a strong erosive character, which truncates the reflectors of the pre-MSC unit (Fig. 11, Fig. 12). The morphology of the MES is generally extremely rugged and sometimes associated with deep incisions beneath the inner and middle shelves (Fig. 11b). This surface is interpreted as the hiatus between the Plio-Quaternary sedimentary cover and the pre-MSC Miocene formations, in agreement with the interpretation of Contrucci (1999) and Mauffret et al. (1999) and also with the succession observed in the Aleria plain (Fig. 4a) and in the two wells Mimosa1 and Martina1 where the Pliocene units are totally lacking, with Pleistocene deposits lying directly upon Oligocene and Burdigalian deposits, respectively, (Fig. 4b).

In the southern part of the Corsica Basin (Orbo Basin), the MES passes laterally into three seismic surfaces ascribed to the BES, TES and IES (Fig. 7, Fig. 15). The BES corresponds to the top of the pre-MSC unit. This surface truncates the pre-MSC unit. Its erosive character is essentially observable based on pre-MSC paleorelief (Fig. 13). The $\mathrm{BU}_{1}$ and $\mathrm{BU}_{2}$ units onlap unconformably the pre-MSC unit (Fig. 7, Fig. 13; Fig. 14; Fig. 16b, Fig. 17). The TES is a continuous and smooth seismic horizon, characterized by the presence of erosional surfaces that locally deeply incise the underlying $B U_{2}$ as well as sometimes the $\mathrm{BU}_{1}$ and pre-MSC seismic units. These incisions as a whole make up a complex system of incised valleys (Fig. 8, Fig. 18). The transition between the $\mathrm{BU}_{1}$ and $B U_{2}$ seismic units, called IES, is a sub-horizontal and highly reflective seismic horizon characterized by the presence of multiple small and shallow depressions. The IES could be interpreted in some places as a rather abrupt facies transition between the $\mathrm{BU}_{1}$ and $\mathrm{BU}_{2}$ units.

\subsubsection{Seismic Units $B U_{2}$ and $B U_{1}$ and their distribution}

The seismic facies of the $B U_{1}$ unit is homogeneous, defined by a set of very high amplitude and intermediate frequency reflectors, which are concordant, corrugated, fairly continuous, but with some heterogeneities, and sub-horizontal (Fig. 13 to Fig. 16). The 
Thinon et al. In press 2016 - Seismic markers of the Messinian Salinity Crisis in an intermediate-depth basin: data for understanding the Neogene evolution of the Corsica Basin (Northern Tyrrhenian Sea) - Marine and Petroleum Geology

thickness of $\mathrm{BU}_{1}$, less than $0.075 \mathrm{~s}$. twtt, is relatively constant, except at the edge of the basin (Fig. 9a), where $\mathrm{BU}_{1}$ onlaps the pre-MSC unit (Fig. 13, Fig. 15, Fig. 16b).

The $\mathrm{BU}_{2}$ seismic unit is sealed and incised by the TES and overlain by the PQ seismic unit. It onlaps $\mathrm{BU}_{1}$ and the pre-MSC seismic unit at the edge of the basin (Fig. 13). The thickness of the $\mathrm{BU}_{2}$ unit can reach $0.1 \mathrm{~s}$. twtt (Fig. 9b), and it consists of some thin lenticular sub-units displaying variable seismic facies (ranging from layered to transparent) which intersect and pinch out (a-f on Fig. 13, Fig. 16b).

The units $\mathrm{BU}_{1}$ and $\mathrm{BU}_{2}$ have been identified only in the Orbo Basin (Fig. 8). It is noteworthy that both $\mathrm{BU}_{1}$ and $\mathrm{BU}_{2}$ are incised by the TES (Fig. 9). The thickness map of $\mathrm{BU}_{1}$ (Fig. 9a) shows that its distribution is slightly wider than $\mathrm{BU}_{2}$, being present on the western flank of the EPR. Its depocentre currently lies along the EPR slightly west of the N-S trending valley. $A$ very thin $\mathrm{BU}_{1}$ unit extends over the Bonifacio margin beyond the Solenzara Fault. The thickness map of $\mathrm{BU}_{2}$ (Fig. 9b) shows a depocentre axis located near the foot of the western edge of the Corsica Basin, and that the $\mathrm{BU}_{2}$ unit does not extend beyond the Solenzara Fault. In summary, we note a decrease in size and a westward migration of the depocentres occurring between the deposition of $\mathrm{BU}_{1}$ and $\mathrm{BU}_{2}$.

\subsubsection{Incision system network}

The incised valley system, associated with the TES, is only observed in the Orbo Basin (Fig. 8). It is made up of three groups of incisions (Fig. 18a). The upstream part of the incision system contains a single N-S trending valley to the North-East (V1), and a wide network of channels to the West (V2). Downstream, to the south, these two systems merge to form a single wide and deep valley (V3), which runs out into the deep basins of the Tyrrhenian Sea.

The N-S trending valley (V1, Fig. 18a) can be observed over more than $100 \mathrm{~km}$ along at the western flank of the EPR. No preserved drainage system is connected to V1 upstream system. Changes in the strike of the N-S trending valley follow along-strike variations of the EPR and coincide with the confluence area of the wide valley network (V2), as well as with small tributaries, such as those coming from the Bonifacio Strait and, to a lesser extent, from the EPR. Although small in size towards the north, the N-S-trending valley widens and 
Thinon et al. In press 2016 - Seismic markers of the Messinian Salinity Crisis in an intermediate-depth basin: data for understanding the Neogene evolution of the Corsica Basin (Northern Tyrrhenian Sea) - Marine and Petroleum Geology

deepens farther south (Fig. 16). Currently located on the western flank of the EPR, the V1 valley was uplifted and tilted towards the west (Fig. 16a, b). The relative uplift may be estimated as at least $110 \mathrm{~m}$.

In the western part of the Orbo basin, an incised valley network (V2, Fig. 7, Fig. 18a) extends over about $660 \mathrm{~km}^{2}$. It is characterized (Fig. 14) by wide, shallow, flat-bottomed valleys that totally or partially incise into the $\mathrm{BU}_{2}$ and $\mathrm{BU}_{1}$ seismic units.

The termination of the incision system is characterized by a single wide and deep valley, striking N-S to W-E, which follows the contour of the EPR (V3, Fig. 16). The outlet of the incision system lies at the same level as the sill between the Corsica Basin and the deep North-Tyrrhenian basins (M, Fig. 18a), where the depth of the base of PQ unit increases from 1.4 to $2.4 \mathrm{~s}$. twtt (750-1000 m of depth difference). It is characterized by a "crow's feet" distribution of the MES isochrons (Fig. 8, Fig. 16a). At its outlet, the valley is at present obstructed by a basement high (called here the Caprera seamount), the western edge of which is interpreted as a fault plane (Fig. 8, Fig. 17). This NE-SW striking fault is in line with Caprera Canyon, is called here the "Caprera Fault". The Caprera basement high is directly overlain by a southeastwards tilted sedimentary cover that is assumed to be pre-MSC in age (Fig. 17). The termination and geometry of the reflectors within the $P Q$ seismic unit along the Caprera Fault suggest a normal displacement during the Pliocene. No samples exist to constrain the lithology of the Caprera basement. The Caprera seamount could thus be interpreted as a small volcanic body on strike with those of the EPR or as a structural high comparable with the granitic Vercelli Seamount (Cocchi et al., in press), the Etruschi and Cialdi Seamounts (Marani and Gamberi, 2004) or the Scoglio d'Affrica Seamount (Fig. 2, Fig. 8). The Caprera seamount appears to have been formed during the Pliocene, in relation with the opening of the Tyrrhenian Sea.

\subsection{Post-MSC sedimentary cover}

The Plio-Quaternary sedimentary cover the overlies pre- and syn-MSC formations across the entire Corsica Basin, as well as under the continental shelf, with the exception of the outcrop zones of the pre-MSC formations (Fig. 8). On the continental shelf offshore from 
Thinon et al. In press 2016 - Seismic markers of the Messinian Salinity Crisis in an intermediate-depth basin: data for understanding the Neogene evolution of the Corsica Basin (Northern Tyrrhenian Sea) - Marine and Petroleum Geology

the Aleria Plain, the incision of the pre-MSC unit (Fig. 11b) is infilled by post-MSC deposits assigned essentially to the Pliocene, in agreement with the onshore outcropping formations (Caron et al., 1990a).

In the Corsica Basin, the isopach map of the PQ seismic unit (Fig. 10, Fig. 12) shows that the Plio-Quaternary depocentre is situated in the northern part of the Corsica Basin, off the Bastia alluvial Plain where large amounts of clastic materials are supplied by the Fium Alto and Golo rivers (Gervais et al., 2004). The thickness of PQ seismic unit may reach more than $1 \mathrm{~s}$ twtt, filling the incisions ascribed to the MSC (Fig. 7 to Fig. 17). The seismic facies of the $P Q$ unit is characterized by a group of reflectors that are weaker in its lower part compared with its upper part. The upper part is characterized by the presence of numerous units attributed to Plio-Quaternary turbiditic deposits (Bellaiche et al., 1994; Gervais et al., 2006). In the lower part of $P Q$, there are a few major unconformities in the centre of the N-S valley, which peter out as they approach the Plio-Quaternary turbiditic deposits (Fig. 12).

The post-MSC sedimentary cover is deformed and faulted offshore from Cap Corse near the northern extremity of the Corsica Basin (Fig. 12). After affecting the pre-MSC units, the normal faults seem to have been reactivated during the Plio-Quaternary with a slightly reverse component. At the southern end of the EPR, near the Caprera Fault and the Caprera seamount, the lower part of $\mathrm{PQ}$ unit cover is likewise deformed and faulted (Fig. 17), producing a bulge which is onlapped by the more recent deposits of the $P Q$ unit. These observations suggest that a regional tectonic phase affected the northern and eastern sectors of the Corsica Basin during the Pliocene. This is in agreement with the field observations carried out on the Neogene Aleria Plain (Guieu et al., 1994b; Serrano et al., 2013), which highlight the onset of northward subsidence during the Middle Pliocene, as well as the deformation resulting from faulting, uplift or tilting along NW-SE axes. This also supports the existence of an intra-Pliocene reactivation as observed in the Tyrrhenian Sea and on the EastSardinia margin (Gaullier et al., 2014) and corroborates the observations of recent uplift established by several authors for northern Corsica (Lenotre et al., 1996; Somme et al., 2011), for the EPR (Gervais et al., 2006) and for Cap Corse (up to 12 Ma ; Jakni et al., 2000). 
Thinon et al. In press 2016 - Seismic markers of the Messinian Salinity Crisis in an intermediate-depth basin: data for understanding the Neogene evolution of the Corsica Basin (Northern Tyrrhenian Sea) - Marine and Petroleum Geology

\section{Discussion}

\subsection{The influence of regional tectonic activity during the MSC}

The spatial distribution of the $\mathrm{BU}_{1}$ and $\mathrm{BU}_{2}$ units (Fig. 8, Fig. 9) suggests that the Golo Basin was an emergent area while the Orbo Basin was subsiding and often flooded during the MSC. This difference could be explained by the tectonic reactivation during the Messinian of older crustal structures, such as the Scoglio d'Affrica horst (Pascucci et al., 1999) and the StAntoine Fault (Fig. 8). It may also be accounted for by the initial morphology of the Corsica Basin including a deepening towards the South.

The difference of spatial distribution between $\mathrm{BU}_{1}$ and $\mathrm{BU}_{2}$ also expresses the development of different depocentres and depositional environments during the MSC:

i) On the southern edge of the Orbo Basin, the Sardo-Bonifacio continental slope is very sparsely overlain, if at all, by Messinian deposits. The southern limit of these deposits emphasizes the role played by the Solenzara Fault. Thus, this crustal-scale fault (Finetti et al., 2005; Mauffret et al., 1999) would have been active during the MSC depositional phases. This is consistent with observations on the western edge of the Aleria Plain, where the Solenzara Fault shows a normal faulting mechanism from the Burdigalian to the Late Miocene (Loÿe-Pilot et al., 2004) and became reactivated during the Late Miocene (Guieu et al., 1994a). The distribution of the syn-MSC depositional units could be explained by a deepening of the Orbo Basin along the Solenzara Fault during the MSC.

ii) Within the Orbo Basin, the depocentre migrated westward. During deposition of the $\mathrm{BU}_{1}$ unit, the basin became wider. This observation is in agreement with the existence of a wide proto-Corsica Basin prior to the MSC and the fact that, at the time, the EPR was not fully developed, but in an embryonic phase (Fig. 3; Cornamusini and Pascucci, 2014). In contrast to the $\mathrm{BU}_{1}$ unit, the depocentre of $\mathrm{BU}_{2}$ was restricted and shifted to the west (Fig. 9). The westward migration and shrinking of the depocentres mostly result from the main build-up of the EPR by expansion and relative uplift, but also from the flexure and relative deepening of 
Thinon et al. In press 2016 - Seismic markers of the Messinian Salinity Crisis in an intermediate-depth basin: data for understanding the Neogene evolution of the Corsica Basin (Northern Tyrrhenian Sea) - Marine and Petroleum Geology

the Orbo Basin. These observations are in agreement with Finetti et al. (2001, 2005), who suggested an increased rate of deepening of the Corsica Basin as early as the Tortonian, and more particularly during the Plio-Quaternary. The southern part of the Corsica basin, corresponding to the Orbo basin, was strongly subsident during the MSC, allowing the creation of a local basin while all surrounding areas were emerged.

\subsection{The syn-MSC deposits}

The stratigraphic position of $\mathrm{BU}_{1}$ and $\mathrm{BU}_{2}$ between the Plio-Quaternary and the preMSC Miocene formations allows us to date them as late Messinian in age, in relation with the MSC. These syn-MSC units are only observed in the Orbo basin, i.e. the southern part of the Corsica basin. Their absence in the Golo Basin indicates that the northern part of the Corsica basin was an emerged area during the entire MSC, in common with the EPR, the Aleria Plain and the Corso-Sardinian margin south of the Solenzara Fault. The marked difference in distribution between $\mathrm{BU}_{1}$ and $\mathrm{BU}_{2}$ (Fig. 8, Fig. 9) also implies that, during the MSC, the area of sedimentation shrank and the depocentre migrated from east to west in the Orbo basin. These observations suggest that, during the MSC, local subsidence was active only in the southern part of the Corsica basin and migrated to the western part of the Orbo basin, close to the Solenzara fault. Thus, the southern part of the Corsica basin subsided while the EPR developed. Local subsidence is likely to have favoured the development of a local endorheic basin, i.e. a perched lake surrounded by emerged land.

Due to the lack of sampling, the lithology of $\mathrm{BU}_{1}$ within the offshore Corsica Basin is still unknown. Considering only its basal seismic facies, $\mathrm{BU}_{1}$ could be interpreted in different ways, i.e.: as an evaporitic unit (Contrucci et al., 2005; Mauffret et al., 1999), a carbonate unit such as the "Calcare di Base" formation (Bowman, 2012), the PLG sequence (Ochoa et al., 2015), or an equivalent of the Lago Mare facies (Hsü et al., 1973; Popescu et al., 2015 and references therein). There is insufficient evidence to either support or exclude these proposed models. However, taking account of the whole regional context (cf. Section 5.6), we interpret 
Thinon et al. In press 2016 - Seismic markers of the Messinian Salinity Crisis in an intermediate-depth basin: data for understanding the Neogene evolution of the Corsica Basin (Northern Tyrrhenian Sea) - Marine and Petroleum Geology

the $\mathrm{BU}_{1}$ unit as an evaporitic, carbonate or mixed unit deposited in a lacustrine environment during a dry period.

The varied seismic facies, geometries and the thin lenticular morphologies of the subunits of the $\mathrm{BU}_{2}$ suggest sub-aqueous terrigenous sedimentation in a lacustrine environment. The deposition of $\mathrm{BU}_{2}$ is likely due to increased terrigenous inputs.

The differences in seismic facies and architecture between $\mathrm{BU}_{1}$ and $\mathrm{BU}_{2}$ units suggest contrasting depositional environments. We propose that, during MSC period, differences between $\mathrm{BU}_{1}$ and $\mathrm{BU}_{2}$ may be explained by climatic variations within the perched lake represented by the Orbo basin. Paleoclimate data indicate an increase in precipitation starting from 5.5 Ma ago (Fauquette et al., 2006; Krijgsman and Meijer, 2008; Rouchy and Caruso, 2006). The depositional environment of $\mathrm{BU}_{1}$ would correspond to a dry climate before $5.5 \mathrm{Ma}$, while more humid conditions from $5.5 \mathrm{Ma}$ onwards led to increased terrigenous inputs.

Considering the proposed ages, according to the stratigraphic model of Gorini et al. (2015), the deposition of $\mathrm{BU}_{2}$ (post 5.5 Ma) belongs to the Messinian Upper Megasequence (MUM, Fig. 19), and would thus be equivalent to the MU and/or UU of Lofi et al. (2011). In that case, the $\mathrm{BU}_{1}$ unit would belong to the Messinian Lower Megasequence (MLM, Fig. 19).

\subsection{Remarkable surfaces of the Messinian Salinity Crisis}

Based on its seismic characteristics and stratigraphic position, the BES represents the lower boundary of the syn-MSC deposits, in agreement with Lofi et al. (2011) and Maillard and Mauffret (2006). In the present study, we correlate the BES with the MES, because the latter is the major unconformity of the Corsica Basin. The BES appears to be a marker of the major sea-level fall of the MSC, dated from 5.9 to 5.6 Ma (Fig. 19; e.g. CIESM, 2008; Gorini et al., 2015).

The IES corresponds to the bounding surface marking the top of the $\mathrm{BU}_{1}$ unit. On the basis of its seismic facies, the IES of the Corsica Basin highlights a change in depositional environment between the sedimentation of $\mathrm{BU}_{1}$ and $\mathrm{BU}_{2}$. There is no clear variation in base level from $\mathrm{BU}_{1}$ to $\mathrm{BU}_{2}$. While IES does not record significant erosion, it might correspond to a period of dessication of the lake. The IES thus reflects the existence of minor local base-level 
Thinon et al. In press 2016 - Seismic markers of the Messinian Salinity Crisis in an intermediate-depth basin: data for understanding the Neogene evolution of the Corsica Basin (Northern Tyrrhenian Sea) - Marine and Petroleum Geology

fluctuations in the Corsica basin, possibly a phase of dessication between the major Messinian sea-level fall and the Pliocene catastrophic reflooding, therefore during a sea-level low stand (Fig. 19).

The TES separates the Plio-Quaternary formations from the syn-MSC units. The TES appears to separate the end of the MSC and the onset of marine deposition in the Corsica Basin. According to Gorini et al. (2015), the TES is a late transgressive erosional surface (Fig. 19) created by the catastrophic reflooding dated as taking place between 5.46 (Bache et al., 2012) and 5.33 Ma (e.g. CIESM, 2008; Gorini et al., 2015). A complex incision system is observed within this surface that probably predates the reflooding, corresponding to the establishment of a drainage system connecting the Orbo basin to the Tyrrhenian Sea.

\subsection{The incised valley system}

The western channel system (V2, Fig. 7, Fig. 16) resembles an incised-valley network. Although the continuity of the incisions between the Aleria continental shelf and the Orbo Basin is not clearly observed, we can reasonably assume that the V2 system was connected to the onshore Corsica drainage system.

The morphology of the N-S-trending valley (V1, Fig. 7, Fig. 16, Fig. 18) displays incisions that are deeper and wider in the downstream portion. This imposes a southerly sediment transit direction towards the deep Tyrrhenian basin. The mouth of this system lies at the same depth as the present-day sill between the Corsica Basin and the present deep Tyrrhenian basin, highlighted by significant erosion and a "crow's feet" distribution of the MES isochrons (Fig. 8, Fig. 18). This suggests a connection between the Corsica Basin and the Tyrrhenian basin associated with drainage of the flow system through the mouth of this incised network. The incised valley $\mathrm{V} 1$ is filled by marine Pliocene deposits. The onset of development of the $\mathrm{V} 1$ system could correspond to the end of $\mathrm{BU}_{2}$ deposition. The existence of angular unconformities in the paleovalley filling suggests that the Pliocene transgression followed the strike of the incised valley system, which was oriented preferentially along the EPR. It is likely that the flow system continued under the effects of currents generated by the existence of relief (enclosed valleys and the EPR itself) until the incised valleys were 
Thinon et al. In press 2016 - Seismic markers of the Messinian Salinity Crisis in an intermediate-depth basin: data for understanding the Neogene evolution of the Corsica Basin (Northern Tyrrhenian Sea) - Marine and Petroleum Geology

completely filled. The orientation of the flow system along the EPR probably reflects a structural control of the uplifting ridge. V1 post-dates the lacustrine MSC deposits of the Orbo Basin. After incision of the V1 system, it is likely that a connection was restored with the Tyrrhenian Sea and that sedimentation resumed in the Orbo basin which was no longer endorheic and became a by-pass area.

The incised-valley system was probably initiated and developed during a sea-level lowstand. The complex interplay between the overall low base level of the MSC and the uplift of the EPR probably favoured localized incisions (V3 and V1). Erosion likely occurred during a period of low sea level, i.e. before 5.46 Ma according to Bache et al. (2012), and definitely before the catastrophic reflooding at $5.33 \mathrm{Ma}$ (Fig. 19). As an age of $5.5 \mathrm{Ma}$ is proposed for the $\mathrm{BU}_{1}-\mathrm{BU}_{2}$ boundary, the drainage of the Orbo basin into the Tyrrhenian Sea through the incised valley system would have taken place between 5.5 and 5.46 Ma.

\subsection{Plio-Quaternary evolution of the Corsica Basin}

The distribution of the Plio-Quaternary unit (Fig. 10a) indicates that the northern part of the Corsica Basin, the Golo Basin, seems to be strongly subsident compared to the Orbo basin. This evolution is contemporaneous with the acceleration of subsidence observed in the northern part of the Neogene Aleria Plain since the Late Pliocene, and the subsidence of the Bastia Plain during the Pliocene-Quaternary (Caron et al., 1990a). Since the Middle Pliocene, the northward tilting of the Corsica Basin induced a migration of the sedimentary depocentre in the Golo Basin.

The MSC markers also provide information about the recent evolution of the Corsica Basin, by recording the deformation. Faulting, tilting and uplift of the MSC markers are observed on the western flank of the EPR and on its southern and northern termination. The Plio-Quaternary formations are also affected, mainly on the northern and southern edges of the Corsica Basin. This deformation highlights the regional tectonic activity since the MSC, such as the development of the EPR and the Orbo Basin followed by the Golo Basin. These observations are consistent with deformation described on the EPR (Bartole, 1995; Contrucci et al., 2005), Cap Corse (Jakni et al., 2000) and the Neogene Aleria Plain (Caron et al., 
Thinon et al. In press 2016 - Seismic markers of the Messinian Salinity Crisis in an intermediate-depth basin: data for understanding the Neogene evolution of the Corsica Basin (Northern Tyrrhenian Sea) - Marine and Petroleum Geology

1990b; Guieu et al., 1994b; Serrano et al., 2013). During the Plio-Quaternary, Alpine Corsica was uplifted and the EPR was formed.

\subsection{Neogene evolution of the Corsica Basin}

Based on the seismic data and maps, we propose a scenario for the evolution of the Corsica Basin from the Miocene to the present day (Fig. 20). The indicated time periods are based on published studies (e.g. CIESM, 2008; Bache et al., 2012; Gorini et al., 2015) and are provided here solely for guidance.

(A) In the Middle Miocene, the EPR and the Corsica Basin are morphologically poorly developed. The Corsica proto-basin is a shallow marine domain with an outer platform resembling the present-day Tuscan Shelf (Cornamusini and Pascucci, 2014). The Corsica Basin is progressively individualized in a context of continuous subsidence since at least the Tortonian.

(B) The MSC sea-level fall from 5.97 (?) to 5.6 (?) Ma leads to the development of an erosional network (marked by the MES and BES) extending from the Corsica proto-basin up to the foot of the East-Sardinian margin.

(C) Sedimentation resumes owing to local tectonics and relief creating a perched lake. A hot and dry climate prevails until 5.5 Ma (Fauquette et al., 2006), leading to evaporite and carbonate deposition $\left(\mathrm{BU}_{1}\right)$. The falling stage sequence of Gorini (MLM; Fig. 19; Gorini et al., $2015)$ is recorded here by the $B E S$ and the deposition of $\mathrm{BU}_{2}$.

(D) From 5.5 Ma, climatic conditions evolve from hot and dry to hot and humid (Fauquette et al., 2006; Rouchy and Caruso, 2006). The increase in precipitation causes greater erosion in the Corsican catchment areas and on the EPR, which is still emerged and being eroded at the time. Subsidence of the Orbo basin increases due to the activity of faults such as the St-Antoine and Solenzara Faults, thus forming an asymmetric rifting basin. This local subsidence allows a favourable accommodation space for the terrigenous deposits of the $\mathrm{BU}_{2}$ unit. During the same period of time, the growth of the EPR induces the westward migration of the $\mathrm{BU}_{2}$ depocentre and accentuates the isolation of the Corsica Basin from the Tyrrhenian Sea. At the same time, the Orbo Basin is reduced in width and the sedimentary 
Thinon et al. In press 2016 - Seismic markers of the Messinian Salinity Crisis in an intermediate-depth basin: data for understanding the Neogene evolution of the Corsica Basin (Northern Tyrrhenian Sea) - Marine and Petroleum Geology

depocentre $\left(\mathrm{BU}_{2}\right.$ unit) migrates to the west. At the end of this phase, the sea level remains low in the Tyrrhenian basin and the Corsica basin is still a perched lake, disconnected from the Tyrrhenian Sea. Under this scenario, $\mathrm{BU}_{2}$ is coeval with the MUM (Fig. 19; Gorini et al., 2015).

(E) Before the catastrophic reflooding (5.33 Ma), which marks the end of the MSC, the Orbo basin is re-connected to the Tyrrhenian Sea via a complex incised-valley network (Fig. 18a) developed during the low sea-level stand initiated by retrogressive erosion. The EPR needs to be sufficiently elevated to influence the strike of this incised valley system (V1). At this time, the perched lake of the Corsica Basin is drained.

(F) At $5.33 \mathrm{Ma}$, the end of the MSC is picked out by a rapid sea-level rise, called the Giant reflooding (Fig. 19; Gorini et al., 2015), leading to renewed submergence of the Corsica Basin. This episode is recorded by a late transgressive erosional surface (TES). Marine deposits fill the incised-valley network and onlap the TES in the Orbo Basin and the MES in the Golo Basin as well as at the edges of the Corsica basin on the EPR. In the Neogene Aleria Plain, the Lower Pliocene marine sediments also onlap onto the pre-MSC formations.

(G) From Intra-Pliocene times, the Corsica Basin undergoes northward tilting. While the Corsica Basin continues to subside, especially close to Corsica, the depocentre migrates northwards from the Orbo Basin into the Golo Basin. At the same time, the Neogene Aleria Plain is also tilted northwards at the foot of the Alpine massif along the St-Antoine Fault, favouring the deposition and preservation of the Upper Pliocene continental deposits (Caron et al., 1990a; Serrano et al., 2013). At the extreme south of the Corsica Basin, a NNE-SSWtrending structural high (the Caprera seamount) emerges masking the mouth of the MSC incision system. The formation of this tilted block may be linked to the Pliocene-Quaternary evolution of the Tyrrhenian Sea (Lentini et al., 2006). The northern (off Cap Corse) and southeastern parts of the Corsica Basin are deformed, uplifted and undergo faulting. The uplift of the eastern edge of the Corsica Basin continues, inducing the westward tilting of the N-Strending valley. The uplift of the Caprera Seamount and northern Corsica, as well as the subsidence of the Corsica Basin, and especially the Golo Basin, continues during the Quaternary, in agreement with the observations of many authors (Jauzein et al., 1982; Caron 
Thinon et al. In press 2016 - Seismic markers of the Messinian Salinity Crisis in an intermediate-depth basin: data for understanding the Neogene evolution of the Corsica Basin (Northern Tyrrhenian Sea) - Marine and Petroleum Geology

et al., 1990b; Lenotre et al., 1996; Jakni et al., 2000; Somme et al., 2011; Gervais et al., 2006; Serrano et al., 2013). The occurrence of late Pliocene-Quaternary tectonic activity in the northern Tyrrhenian Sea, locally characterized by inversion tectonics, suggests active mechanisms (intraplate compression?) superimposed on post-rift subsidence (Spadini and Wezel, 1994).

\section{Conclusions}

Based on new interpretation of HR seismic reflection profiles and new regional maps, we establish that the MSC is recorded through specific deposits and remarkable surfaces in the Corsica Basin, located between the East-Corsica continental margin and the deep Tyrrhenian basins.

The study of these seismic markers leads us to propose a syn- and post-MSC evolution for the Corsica Basin. At the beginning of the MSC, the Corsica Basin was emerged above sea level. During the MSC, the subsidence of the southern part (Orbo Basin) of the Corsica Basin favoured the deposition and preservation of two syn-MSC units $\left(\mathrm{BU}_{1}\right.$ and $\left.\mathrm{BU}_{2}\right)$. The Orbo basin was probably a perched lake at that time, associated with the accumulation of lacustrine evaporites or carbonates $\left(\mathrm{BU}_{1}\right)$ and terrigenous sediments $\left(\mathrm{BU}_{2}\right)$. The syn-MSC sedimentation suggest contrasting depositional environments that can be explained by an intra-MSC climate change from dry to more humid conditions at around 5.5 Ma.

At least three remarkable erosional surfaces are highlighted. The basal erosional surfaces (MES and BES) are interpreted as resulting from subaerial erosion in response to the huge sea-level drop in the Mediterranean and mark the onset of the MSC. Erosion on the continental margin (MES) lasted until at least the Pliocene reflooding. The Top Erosional Surface (TES), which is placed at the base of the Plio-Quaternary sedimentary succession, appears to represent a late transgressive erosional surface induced by the catastrophic reflooding, marking the end of the MSC. Combined with the TES, a large and complex incised-valley network extending over the Orbo Basin was initiated by retrogressive erosion during a relative fall in sea level, i.e. the low stand phase of the MSC. Since the beginning of 
Thinon et al. In press 2016 - Seismic markers of the Messinian Salinity Crisis in an intermediate-depth basin: data for understanding the Neogene evolution of the Corsica Basin (Northern Tyrrhenian Sea) - Marine and Petroleum Geology

the MSC, the Corsica basin behaved as an endorheic perched lake, disconnected from the Tyrrhenian Sea until the end of the MSC when incision took place. Before the catastrophic Pliocene reflooding event, the Corsica basin was connected again to the deep Tyrrhenian basins.

While the detailed markers, stratigraphic units and remarkable surfaces of the MSC have been already identified in the East-Corsica region, our study further demonstrates the control of the active tectonic setting on these records. The distribution of syn-MSC deposits was influenced by the subsidence of the Orbo Basin along the Solenzara and St-Antoine Faults and by the build-up of the Elba-Pianosa Ridge. Since the Pliocene, the tectonic setting has changed: the northern part (Golo Basin) of the Corsica Basin has subsided, whereas the northern and southern edges of the Corsica Basin, as well as the Elba-Pianosa Ridge, have undergone significant deformation.

\section{Acknowledgements}

We are thankful to all colleagues and students of the BRGM, the University of Corte, the University of Western Brittany, the University of Perpignan and the University of Lille, as well as the Geosciences Azur laboratory, who contributed to the data acquisition and scientific discussions. Our thanks go to the crew of the oceanographic cruises (INSU), the offshore Messinian scientific team of the ECLIPSE programme, and the French Geological Mapping programme and RGF-continental shelf of the French Geological Survey for funding this study. We particularly wish to thank M.D. Loÿe for her help. The reviewers (C. Gorini and G. Cornamusini) are greatly acknowledged for their comments and recommendations which helped us to significantly improve an early draft of the manuscript. We also thank $M$. Carpenter for language editing.

\section{REFERENCES}

Aleria, Group, Le Messinien du Canal de Corse et des bassins nord-tyrrhéniens, C. R. Acad. Sci. Pari 288, 1979, 1521-1524. 
Thinon et al. In press 2016 - Seismic markers of the Messinian Salinity Crisis in an intermediate-depth basin: data for understanding the Neogene evolution of the Corsica Basin (Northern Tyrrhenian Sea) - Marine and Petroleum Geology

Argnani A., Plate motion and the evolution of Alpine Corsica and Northern Apennines, Tectonophysics 579, 2012, 207-219.

Bache F., Olivet J.L., Gorini C., Aslanian D., Labails C. and Rabineau M., Evolution of rifted continental margins: the case of the Gulf of Lions (Western Mediterranean Basin), Earth Planet. Sci. Lett. 292, 2010, 345-356.

Bache F., Popescu S., Rabineau M., Gorini C., Suc J., Clauzon G., Olivet J.L., Rubino J.L., Melinte-Dobrinescu M.C., Estrada F., Londeix L., Armijo R., Meyer B., Jolivet L., Jouannic G., Leroux E., Aslanian D., Reis A.T.D., Mocochain L., Dumurdzanov N., Zagorchev I., Lesic V., Tomic D., Cagatay M.N., Brun J.P., Sokoutis D., Csato I., Ucarkus G. and Çakir Z., A two-step process for the reflooding of the Mediterranean after the Messinian Salinity Crisis, Basin Res. 24, 2012, 125-153.

Bartole R., The North Tyrrhenian-Northern Apennines post-collisional system: constraints for a geodynamic model, Terra Nova 7, 1995, 7-30.

Bellaiche G., Pautot G., Gaullier V., Vanney J.R. and Droz L., Les appareils sédimentaires de la marge orientale de la Corse: interprétation hydrodynamique et implications structurales, Mar. Geol. $316,1993,513-517$

Bellaiche G., Droz L., Gaullier V. and Pautot G., Small submarine fans on the eastern margin of Corsica: sedimentary significance and tectonic implications, Mar. Geol. 117, 1994, 177-185.

Bigi G., Castellarin A., Catalano R., Coli M., Cosentino D., Dal Piaz G.V., Lentini F., Parotto M., Patacca E., Praturlon A., Salvini F., Sartori R., Scandone P. and Vai G.B., Synthetic Structuralkinematic Map of Italy, Scale 1:2.000.000: CNR, 1989, Progetto Finalizzato Geodinamica; Roma.

Bossio A., Costantini A., Foresi L.M., Lazzarotto A., Mazzanti R., Mazzei R., Pascucci V., Salvatorini G., Sandrelli F. and Terzuoli A., Neogene-Quaternary sedimentary evolution in the western side of the northern Apennines (Italy), Mem. Soc. Geol. It. 52, 1998, 513-525.

Bossio A., Cornamusini G., Ferrandini J., Ferrandini M., Foresi L.M., Mazzanti R., Mazzei R. and Salvatorini G., L'evoluzione sedimentaria neogenica dell'area tirrenica settentrionale (Toscana Marittima, Isola di Pianosa, Bacino di Aleria), In: Actes du Congrès Environnement et Identité en Méditerranée, Université de Corse, Juin 2000. Interreg II, 2000, 72-79.

Bowman S.A., A comprehensive review of the MSC facies and their origins in the offshore Sirt Basin, Libya, Pet. Geosci. 18, 2012, 457-469. 
Thinon et al. In press 2016 - Seismic markers of the Messinian Salinity Crisis in an intermediate-depth basin: data for understanding the Neogene evolution of the Corsica Basin (Northern Tyrrhenian Sea) - Marine and Petroleum Geology

Brunet C., Monié P., Jolivet L. and Cadet J.P., Migration of compression and extension in the Tyrrhenian Sea, insights from 40Ar/39Ar ages on micas along a transect from Corsica to Tuscany, Tectonophysics 321 (1), 2000, 127-155.

Calcagno P., Thinon I., Courrioux G., Guillen A. and Guennoc P., 3D geometric modelling: a tool for margin and basin interpretation illustrated with the Eastern Corse case-study (NW Mediterranean sea). Réunion des Sciences de la Terre, Joint Earth Sciences Meeting, 2004, Société Géologique de France - Geologische Vereinigung; Strasbourg.

Calcagno P., Courrioux G., Guillen A., Fitzgerald D. and McInerney P., How 3D implicit geometric modelling helps to understand geology: the 3DGeoModeller methodology, In: Proceedings International Association for Mathematical Geology XIth International Congress, 2006, Université de Liège; Belgium, 4, CD-ROM.

Calvès G., Toucanne S., Jouet G., Charrier S., Thereau E., Etoubleau J., Marsset T., Droz L., Bez M., Abreu V., Jorry S., Mulder T. and Lericolais G., Inferring denudation variations from the sediment record; an example of the last glacial cycle record of the Golo Basin and watershed, East Corsica, western Mediterranean sea, Basin Res. 24, 2012, 1-22, http://dx.doi.org/10.1111/j.13652117.2012.00556.x.

Carmignani L., Decandia F.A., Fantozzi P.L., Lazzarotto A., Liotta D. and Meccheri M., Tertiary extensional tectonics in Tuscany (Northern Apennines, Italy), Tectonophysics 238, 1994, 295-315.

Carmignani L., Decandia A., Disperati L., Fantozzi P.L., Lazzarotto A., Liotta D. and Oggiano G., Relationships between the Tertiary structural evolution of the Sardinia-Corsica-Provençal domain and the Northern Apennines, Terra Nova 7, 1995, 128-137.

Carmignani L., Conti P., Cornamusini G. and Meccheri M., The internal Northern Apennines, the Northern Tyrrhenian Sea and the Sardinia-Corsica block, In: Crescenti U., D'Offizi S., Merlino S. and Sacchi S., (Eds.), Geology of Italy, Special vol. 32, 2004, IGC Florence, 59-77.

Carminati E. and Doglioni C., Alps vs. Apennines: the paradigm of a tectonically asymmetric Earth, Earth Sci. Rev. 112, 2012, 67-96.

Caron J.M., Loÿe-Pilot M.D., Conchon O. and Scius H., Carte Géologique de la France (1/50000), feuille Pietra-di-Verde (1115). Orléans: Bureau de recherches géologiques et minières, 1990a, Notice explicative par Caron, J.M., Loÿe-Pilot, M.D., Conchon, O., Scius, H. (1990). 
Thinon et al. In press 2016 - Seismic markers of the Messinian Salinity Crisis in an intermediate-depth basin: data for understanding the Neogene evolution of the Corsica Basin (Northern Tyrrhenian Sea) - Marine and Petroleum Geology

Caron J.M., Loÿe-Pilot M.D., avec la collaboration de Conchon O., Dominici R., Scius H. and Vautrelle C., Notice explicative. Carte Géologique de la France (1/50000), feuille Pietra-di-Verde (1115), 1990b, Bureau de recherches géologiques et minières; Orléans, 51, Carte géologique par Caron J.M., Loÿe-Pilot M.D., Conchon O., Scius H. (1990).

Cavazza W., DeCelles P.G., Fellin M.G. and Paganelli L., The Miocene Saint-Florent Basin in northern Corsica: stratigraphy, sedimentology, and tectonic implications, Basin Res. 19, 2007, 507527.

Cherchi A. and Trémolières P., Nouvelles données sur l'évolution structurale au Mésozoïque et au Cénozoïque de la Sardaigne et leurs implications géodynamiques dans le cadre méditerranéen, $\mathrm{C}$. R. Acad. Sci. Paris 298, 1984, 889-894.

CIESM, The Messinian Salinity Crisis from mega-deposits to microbiology - a consensus report. $N^{\circ} 33$, In: Briand F., (Ed), CIESM Workshop Monographs, 2008, 168, (Monaco).

Cocchi L., Masetti G., Muccini F. and Carmisciano C., Geophysical Mapping of Vercelli Seamount: Implications for Miocene Evolution of the Tyrrhenian Back Arc Basin, 2015, Geoscience Frontiers, 1-15, (in press) http://dx.doi.org/10.1016/j.gsf.2015.06.006.

Contrucci I., Structures profondes du bassin Nord Ligure et structures du bassin Nord Tyrrhénien, PhD1999, Univ. de Corte; Corse, France, 217.

Contrucci I., Mauffret A., Brunet C., Nercessian A., Béthoux N. and Ferrandini J., Deep structure of the North Tyrrhenian Sea from multi-channel seismic profiles and on land wide angle reflection/refraction seismic recording (LISA cruise): geodynamic implications, Tectonophysics 406, 2005, 141-163.

Cornamusini G., Foresi L.M., Bossio A., Ferrandini J., Ferrandini M., Mazzanti R., Mazzei R. and Salvatorini G., II Miocene superiore - Pliocene della Piana di Aleria (Corsica), In: Actes du Congrès Environnement et Identité en Méditerranée, Juin 2000, Université de Corse; Interreg II, 170-174.

Cornamusini G., Lazzarotto A., Merlini S. and Pascucci V., Eocene-Miocene evolution of the north Tyrrhenian Sea, Boll. Soc. Geol. It 1, 2002, 769-787.

Cornamusini G., Foresi L.M., Dall'antonia B., Bossio A., Mazzei R. and Salvatorini G., The Miocene of Pianosa Island: key to understanding the opening of the Northern Tyrrhenian back-arc basin (Central Mediterranean), J. Geol. Soc. 171, 2014, 801-819. 
Thinon et al. In press 2016 - Seismic markers of the Messinian Salinity Crisis in an intermediate-depth basin: data for understanding the Neogene evolution of the Corsica Basin (Northern Tyrrhenian Sea) - Marine and Petroleum Geology

Cornamusini G. and Pascucci V., Sedimentation in the Northern Apennines-Corsica tectonic knot (Northern Tyrrhenian Sea, Central Mediterranean): offshore drilling data from the Elba-Pianosa Ridge, Int. J. Earth Sci. 103, 2014, 821-842.

Dalla Valle G. and Gamberi F., Erosional sculpting of the Caprera confined deep-sea fan as a result of distal basin-spilling processes (eastern Sardinian margin, Tyrrhenian Sea), Mar. Geol. 268, 2010, 55-66.

Dalla Valle G. and Gamberi F., Slope channel formation, evolution and backfilling in a wide shelf, passive continental margin (northeastern sardinia slope, central tyrrhenian sea), Mar. Geol. 286 (1-4), 2011, 95-105.

Dewey J.F., Helman M.L., Knott S.D., Turco E. and Hutton D.H.W., Kinematics of the western Mediterranean, 1989, Geological Society; London, 265-283, Special Publications, 45.

Dini A., Innocenti F., Rocchi S., Tonarini S. and Westerman D.S., The magmatic evolution of the late Miocene laccolith-pluton-dyke granitic complex of Elba Island, Italy, Geol. Mag. 139 (3), 2002, 257279.

Doglioni C., Mongelli F. and Pieri P., The Puglia uplift (SE-Italy): an anomaly in the foreland of the Apenninic subduction due to buckling of a thick continental lithosphere, Tectonics 13 (5), 1994, $1309-1321$

Facenna C., Mattei M., Funiciello R. and Jolivet L., Styles of back-arc extension in the Central Mediterranean, Terra Nova 9, 1997, 126-130.

Fauquette S., Suc J., Bertini A., Popescu S., Warny S., Bachiri Taoufiq N., Perez Villa M., Chikhi H., Feddi N., Subally D., Clauzon G. and Ferrier J., How much did climate force the Messinian Salinity Crisis? Quantified climatic conditions from pollen records in the Mediterranean region, Palaeogeogr. Palaeoclimatol. Palaeoecol. 238, 2006, 281-301.

Fellin M.G., Picotti V. and Zattin M., Neogene to Quaternary rifting and inversion in Corsica: retreat and collision in the western Mediterranean, Tectonics 24, 2005, 1-29.

Ferrandini J., Ferrandini M., Suc J., Rouchy J.M., Saint Martin S., Popescu S., Saint Martin J. and Jehasse O., Late Miocene and Early Pliocene deposits of the Aleria area, In: 4th Congress EIM, Corte Field, 18, 2004.

Finetti I.R., Boccalettib M., Boninic M., Del Bena A., Geletti R., Pipana M. and Sanib F., Crustal section based on CROP seismic data across the North Tyrrhenian-Northern Apennines-Adriatic Sea, Tectonophysics 343 (3-4), 2001, 135-163. 
Thinon et al. In press 2016 - Seismic markers of the Messinian Salinity Crisis in an intermediate-depth basin: data for understanding the Neogene evolution of the Corsica Basin (Northern Tyrrhenian Sea) - Marine and Petroleum Geology

Finetti I.R., Del Ben A., Fais S., Forlin E., Klingelé E., Lecca L., Pipan M. and Prizzon A., Crustal Tectono-startigraphic setting and geodynamics of the Corso-Sardinian block from new CROP seismic data, In: Finetti I.R., (Ed), CROP PROJECT - Deep Seismic Exploration of the Central Mediterranean and Italy, Atlas in Geoscience ed, 2005, Elsevier, 413-446.

Gabin R., Resultats d'une étude de sismique reflexion dans le Canal de Corse, et de sondeur de vase dans le Bassin Toscan, Mar. Geol. 1972, 267-286.

Gattacceca J., Deino A., Rizzo R., Jones D.S., Henry B., Beaudoin B. and Vadeboin F., Miocene rotation of Sardinian: new paleomagnetic and geochronolical conctraints and geodynamic implications, Earth Planet. Sci. Lett. 258, 2007, 359-377.

Gaullier V., Lofi J., Chanier F., Déverchère J., Dutreuil V., Gorini C., Loncke L., Maillard A., Pascucci V., Thinon I., Sellier N., Suc J. and Clauzon G., The messinian event on the eastern sardinian margin (tyrrhenian sea) from seismic study; new insights from the "metyss" cruise (June 2009), In: Proceedings of the 27th IAS Meeting of Sedimentologists, 2009, 73.

Gaullier V., Chanier F., Lymer G., Vendeville B.C., Maillard A., Thinon I., Lofi J., Sage F. and Loncke L., Salt tectonics and crustal tectonics along the Eastern Sardinian margin, Western Tyrrhenian: new insights from the "METYSS 1" cruise, Tectonophysics 615-616, 2014, 69-84.

Gervais A., Savoye B., Piper D.J.W., Mulder T., Cremer M. and Pichevin L., Present morphology and depositional architecture of a sandy confined submarine system: the Golo depositional system (Eastern margin of Corsica), In: Lomas S.A. and Joseph P., (Eds.), Confined Turbidite System Sedimentology, 2004, Geological Society of London, 59-89, Special Publication, 222.

Gervais A., Mulder T., Savoye B. and Gonthier E., Sediment distribution and evolution of sedimentary processes in a small sandy turbidite system (Golo system, Mediterranean Sea): implications for various geometries based on core framework, Geo-Marine Lett. 26, 2006, 373-395.

Gorini C., Montadert L. and Rabineau M., New imaging of the salinity crisis: Dual Messinian lowstand megasequences recorded in the deep basin of both the eastern and western Mediterranean, Mar. Petrol. Geol. 66 (1), 2015, 278-294.

Greve S., Paulssen H., Goes S. and Van Bergen M., Shear-velocity structure of the Tyrrhenian Sea: tectonics, volcanism and mantle (de)hydration of a back-arc basin, Earth Planet. Sci. Lett. 400, 2014, 45-53. 
Thinon et al. In press 2016 - Seismic markers of the Messinian Salinity Crisis in an intermediate-depth basin: data for understanding the Neogene evolution of the Corsica Basin (Northern Tyrrhenian Sea) - Marine and Petroleum Geology

Gueguen E., Doglioni C. and Fernàndez M., On the post-25 Ma geodynamic evolution of the western Mediterranean, Tectonophysics 298, 1998, 259-269.

Guennoc P., Réhault J.P. and Thinon I., West-Corsica Margin: MSC basinal units, In: Lofi J., et al., (Eds.), Mémoires de la Société géologique de France and World Geological Map Commission ed, $2011,1-72$

Guieu G., Loÿe-Pilot M.D., Mathely J.N., Bercovici C. and Gaviglio P., Carte géologique de la France (1/50000), Feuille Cervione (1111), 1994a, BRGM; Orléans, Notice explicative par G. Gieu, M.D. Loÿe-Pilot, D. Lahondère, J. Ferrendini (1994), 50p.

Guieu G., Loÿe-Pilot M.D., Lahondère D. and Ferrendini J., Notice explicative. Carte géologique de la France (1/50000), Feuille Cervione (1111), 1994b, BRGM; Orléans, 50, Carte Géologique par Gieu G., Loÿe-Pilot, M.D., J.N. Mathely, C. Bercovici, P. Gaviglio (1994).

Heezen B.C., Fischer A.G., Boyce R.E., Bukry D., Douglas R.G., Garrison R.E., Kling S.A., Krasheninnikov V.A., Lisitzin A.P. and Pimm A.C., Site 50. Initial Reports of the Deep Sea Drilling Project 6, 1971, 195-221.

Hsü K.J., Cita M.B. and Ryan W.B.F., The origin of the Mediterranean evaporites, In: Ryan W.B.F., et al., (Eds.), Initial Reports of the Deep Sea Drilling Project 13, Part 2, 1973, U.S. Government Printing Office; Washington D.C, 1203-1231.

Hsü K., Montadert L., Bernoulli D., Cita M.B., Erikson A., Garrison R.E., Kidd R.B., Melieres F., Müller C. and Wright R.H., Initial Reports of the Deep Sea Drilling Project vol. 42, 1978, U.S. Government Printing Office; Washington, Parte 1.

laccarino S. and Bossio A., Paleoenvironment of uppermost Messinian sequences in the western Mediterranean (Sites 974, 975, and 978), In: Zahn R., Comas M.C. and Klaus A., (Eds.), Proceedings of the Ocean Drilling Program, College Station, TX, Scientific Results 161, 1999, 529-541.

Jakni B., Poupeau G., Sosson M., Rossi P., Ferrandini J. and Guennoc P., Cenozoic denudations in Corsica: an analysis from apatite fission-track thermochronology, Comptes Rendus I'Acad. Sci. Series IIA 331 (12), 2000, 775-782.

Jauzein A., Orszag-Sperber F., Pilot M.D., Notice explicative. Carte géologique de la France (1/50000), Feuille Ghisonaccia (1119), 1976, 1-28. BRGM; Orléans.

Jolivet L., Augier R., Robin C., Suc J. and Rouchy J.M., Lithospheric-scale geodynamic context of the Messinian Salinity Crisis, Sediment. Geol. 188-189, 2006, 9-33. 
Thinon et al. In press 2016 - Seismic markers of the Messinian Salinity Crisis in an intermediate-depth basin: data for understanding the Neogene evolution of the Corsica Basin (Northern Tyrrhenian Sea) - Marine and Petroleum Geology

Kastens K.A. and Mascle J., The geological evolution of the Tyrrhenian Sea: an introduction to the scientific results of ODP Leg 107, In: Kastens K.A., Mascle J., et al., (Eds.), Proceedings of the Ocean Drilling Program, Scientific Results, 1990, 3-26.

Krijgsman W., Hilgen F.J., Raffi I., Sierro F.J. and Wilson D.S., Chronology, causes and progression of the Messinian Salinity Crisis, Nature 400, 1999, 652-655.

Krijgsman W. and Meijer P.T., Depositional environments of the Mediterranean "Lower Evaporites" of the Messinian Salinity Crisis: constraints from quantitative analyses, Mar. Geol. 253, 2008, 73-81.

Lenotre N., Ferrandini J., Delfau M. and Panighi J., Mouvements verticaux actuels de la Corse (France) par comparaison de nivellements, C. R. Acad. Sci. Paris 323, 1996, 957-964.

Lentini F., Carbone S. and Guarnieri P., Collisional and postcollisional tectonics of the ApenninicMaghrebian orogen (Sourthern Italy), In: Dilek Y. and Pavlides S., (Eds.), Postcollisional Tectonics and Magmatism in the Mediterranean Region and Asia: Geological Society of America Special Paper 409, 2006, 57-81, http://dx.doi.org/10.1130/2006.2409(04).

Letouzey J., Wannesson J. and Cherchi A., Apport de la microtectonique au problème de la rotation du bloc corso-sarde, C. R. Acad. Sci. Paris 294, 1982, 595-602.

Lofi J., Gorini C., Berné S., Clauzon G., Dos Reis A.T., Moutain G., Ryan W.B.F. and Steckler M.S., Erosional processes and paleo-environmental changes in the western Gulf of Lion (SW France) during the Messinian Salinity Crisis, Mar. Geol. 217, 2005, 1-30.

Lofi J., Déverchère J., Gaullier V., Gillet H., Gorini C., Guennoc P., Loncke L., Maillard A., Sage F. and Thinon I., Seismic atlas of the Messinian Salinity Crisis markers in the Mediterranean and Black Sea, Mém. Soc. Géol. CCGM 179, 2011, 1-72 + CD.

Loÿe-Pilot M.D. and Magné J., La formation de Péri (Plain e orientale corse):; formation continentale à paléosols d'âge post-Tortonien, Comptes Rendus Hebd. Sci. l'Acad. Sci. Série Sci. Nat. $280,1978,247-250$.

Loÿe-Pilot M.D. and Magné J., Livret-guide de l'itinéraire Plaine orientale, Excursion Groupe Fr. d'étude Néogène Corse 4 (8), septembre 1989, 20.

Loÿe-Pilot M.D., Durand-Delga M., Feinberg H., Gourinard Y. and Magné J., Les formations burdigaliennes de Corse orientale dans leur cadre géodynamique, Comptes Rendus Geosci. 336 (10), 2004, 919-930. 
Thinon et al. In press 2016 - Seismic markers of the Messinian Salinity Crisis in an intermediate-depth basin: data for understanding the Neogene evolution of the Corsica Basin (Northern Tyrrhenian Sea) - Marine and Petroleum Geology

Loÿe-Pilot M.D. and Ferrandini M., L'extension tardi-alpine. Les formations miocènes (postnappe), Géochronique n 132, 2014, 41-44.

Magné J., Orszag-Sperber F. and Pilot M.D., La formation d'Aléria: le problème de la limite Miocène-Pliocène en Plain e orientale corse, C. R. Acad. Sci. Paris 280, 1975, 247-250.

Maillard A. and Mauffret A., Relationship between erosion surfaces and Late Miocene Salinity Crisis deposits in the Valencia Basin (northwestern Mediterranean): evidence for an early sea-level fall, Terra Nova 18, 2006, 321-329.

Maillard A., Driussi O., Lofi J., Briais A., Chanier F., Hübscher C. and Gaullier V., Record of the Messinian Salinity Crisis in the SW Mallorca area (Balearic Promontory, Spain), Mar. Geol. 357, 2014, 304-320.

Malinverno A. and Ryan W., Extension in the Tyrrhenian sea and shortening in the Apennines as result of arc migration driven by sinking of the lithosphere, Tectonics 5, 1986, 227-245.

Manzi V., Gennari R., Hilgen F., Krijgsman W., Lugli S., Roveri M. and Sierro F., Age refinement of the Messinian Salinity Crisis onset in the Mediterranean, Terra Nova 25, 2013, 315-322.

Marani M.P. and Gamberi F., Structural framework of the Tyrrhenian Sea unveiled by seafloor morphology, In: Marani M.P., Gamberi F. and Bonatti E., (Eds.), From Seafloor to Deep Mantle: Architecture of the Tyrrhenian Backarc Basin, Memorie Descrittive Carta Geologica d'Italia, v XLIV, 2004, 97-108.

Mauffret A., Etude géodynamique de la marge des iles Baléares, PhD, 1976, Faculté des Sciences; Paris, 137p.

Mauffret A., Contrucci I. and Brunet C., Structural evolution of the Northern Tyrrhenian Sea from new seismic data, Mar. Petrol. Geol. 16, 1999, 381-407.

Mele G. and Sandvol E., Deep crustal roots beneath the northern Apennines inferred from teleseismic receiver functions, Earth Planet. Sci. Lett. 211 (1-2), 2003, 69-78.

Montadert L., Sancho J., Fial J.P. and Debysser J., De l'âge tertiaire de la série salifère responsable des structures diapiriques en Méditerranée occidentale (Nord-Est des Baléares), C. R. Acad. Sc. Paris 271, 1970, 812-815.

Moussat E., Evolution de la Mer Tyrrhénienne centrale et orientale et de ses marges septentrionales en relation avec la néotectonique dans l'arc calabrais, PhD, 1983, 1-122. 
Thinon et al. In press 2016 - Seismic markers of the Messinian Salinity Crisis in an intermediate-depth basin: data for understanding the Neogene evolution of the Corsica Basin (Northern Tyrrhenian Sea) - Marine and Petroleum Geology

Ochoa D., Sierro F.J., Lofi J., Maillard A., Flores J. and Suárez M., Synchronous onset of the Messinian evaporite precipitation: first Mediterranean offshore evidence, Earth Planet. Sci. Lett. 427, $2015,112-124$.

Orszag-Sperber F. and Pilot M.D., Grands traits du néogène de Corse, Bull. Soc. Géol. Fr. 18, 1976, 1183-1187.

Orszag-Sperber F., Le Néogène de la Corse et ses relations avec la géodynamique de la Méditerranée occidentale, 1978, Thèse d'état. Paris Sud. 328 p.

Orszag-Sperber F., Rouchy J.M. and Blanc-Valleron M.M., La transition Messinien-Pliocène en Méditerranée orientale (Chypre): la période du Lago-Mare et sa signification. The transition MessinianPliocene in eastern Mediterranean (Cyprus): the 'Lago-Mare' deposits and their significance, C. R. Acad. Sci. Paris 331 (7), 2000, 483-490.

Ottmann F., Les formations pliocènes et quaternaires sur le littoral corse, Mém. Soc. Géol. Fr. 84, 1958, 1-176.

Pasci S., Tertiary transcurrent tectonics of North-Central Sardinia, Bull. Soc. Géol. Fr. 168, 1997, $301-312$.

Pascucci V., Tyrrhenian Sea extension north of the Elba Island between Corsica and western Tuscany (Italy), Boll. Soc. Geol. It. (1), 2002, 819-828.

Pascucci V., Merlini S. and Martini P., Seismic stratigraphy of the Miocene-Pleistocene sedimentary basins of the Northern Tyrrhenian Sea and western Tuscany (Italy), Basin Res. 11 (4), 1999, 337.

Peccerillo A., Plio-Quaternary magmatism in Italy, Episodes 26, 2003, 222-226.

Popescu S.-M., Dalibard M., Suc J.-P., Barhoun N., Melinte-Dobrinescu M.-C., Bassetti M.A., Deaconu F., Head M.J., Gorini C., Do Couto D., Rubino J.-L., Auxietre J.-L. and Floodpage J., Lago Mare episodes around the Messinian-Zanclean boundary in the deep southwestern Mediterranean, Mar. Petrol. Geol. 66 (Part 1), 2015, 55-70.

Prada M., Sallarès V., Ranero C.R., Vendrell M.G., Grevemeyer I., Zitellini N. and de Franco R., Seismic structure of the Central Tyrrhenian basin: Geophysical constraints on the nature of the main crustal domains, J. Geophys. Res. Solid Earth J. Geophys. Res. Solid Earth 119 (1), 2014, 52-70.

Réhault J.P., Moussat E. and Fabbri A., Structural evolution of the Tyrrhenian backarc basin, Mar. Geol. 74, 1987, 1-9. 
Thinon et al. In press 2016 - Seismic markers of the Messinian Salinity Crisis in an intermediate-depth basin: data for understanding the Neogene evolution of the Corsica Basin (Northern Tyrrhenian Sea) - Marine and Petroleum Geology

Reynaud J.Y., Ferrandini M., Ferrandini J., Santiago M., Thinon I., André J.P., Barthet Y., Guennoc P. and Tessier B., From non-tidal shelf to tide-dominated strait: the Miocene Bonifacio Basin, Southern Corsica, Sedimentology 60 (2), 2013, 599-623.

Riding R., Braga J.C., Martin J.M. and Sanchez-Almazo I.M., Mediterranean Messinian Salinity Crisis: constraints from a coeval marginal basin, Sorbas, southeastern Spain, Mar. Geol. 146, 1998, 120.

Rouchy J.M. and Caruso A., The Messinian Salinity Crisis in the Mediterranean basin: a reassessment of the data and an integrated scenario, Sediment. Geol. 188-189, 2006, 35-67.

Roveri M., Gennari R., Lugli S. and Manzi V., The Terminal Carbonate Complex: the record of sea-level changes during the Messinian Salinity Crisis, GeoActa 8, 2009, 63-77.

Roveri M., Flecker R., Krijgsman W., Lofi J., Lugli S., Manzi V., Sierro F., Bertini A., Camerlenghi A., De Lange G., Govers R., Hilgen F., Hübscher C., Meijer P.T. and Stoica M., The Messinian Salinity Crisis: past and future of a great challenge for marine sciences, Mar. Geol. 50th Anniv. Spec. Issue 352 (1), 2014, 25-58.

Ryan W.B.F., Hsü K.J., Cita M.B., Dumitrica P., Lort J., Maync W., Nesteroff W.D., Pautot G., Stardner H. and Wesel F.C., Boundary of Sardinian slope with Baelaric Abyssal Plain - sites 133 and 134, In: Ryan W.B.F., Hsü K.J., et al., (Eds.), Initial Reports of the Deep Sea Drilling Project, 1973, U.S. Government Printing Office; Washington D.C., 465-514.

Saint Martin S., Saint Martin J., Ferrandini J. and Ferrandini M., La microflore de diatomées au passage mio-pliocène en Corse, Geobios 40, 2007, 375-390.

Serrano O., Allanic C. and Magar M., Synthèse géologique du bassin tertiaire de la Plain e Orientale Corse - Liaison Terre-Mer entre San Nicolao et Solenzara, Rapport final. BRGM RP-62303FR2013, 178, 137ill.

Serri G., Innocenti F. and Manetti P., Magmatism from Mesozoic to Present: petrogenesis, timespace distribution and geodynamic implications, In: Vai G.B. and Martini I.P., (Eds.), Anatomy of an Orogen: the Apennines and Adjacent Mediterranean Basins, 2001, Kluwer Ac Pub., 77-104.

Somme T.O., Piper D.J.W., Deptuck M.E. and Helland-Hansen W., Linking onshore-offshore sediment dispersal in the golo source-to-sink system (Corsica, France) during the Late Quaternary, J. Sediment. Res. 81, 2011, 118-137.

Spadini G., Wezel F.C., Structural evolution of the "41st parallel zone": Tyrrhenian Sea, Terra Nova, 6, 1994, 552-562. 
Thinon et al. In press 2016 - Seismic markers of the Messinian Salinity Crisis in an intermediate-depth basin: data for understanding the Neogene evolution of the Corsica Basin (Northern Tyrrhenian Sea) - Marine and Petroleum Geology

Speranza F., Villa I.M., Sagnotti L., Florindo F., Cosentino D., Cipollari P. and Mattei M., Age of the Corsica-Sardinia rotation and Liguro-Provençal Basin spreading: new paleomagnetic and $\mathrm{Ar} / \mathrm{Ar}$ evidence, Tectonophysics 347, 2002, 231-251.

Stanley D.J., Réhault J.P. and Stuckenrath R., Turbid-Layer bypassing model: the Corsian trough, northwestern mediterranean, Mar. Geol. 37, 1980, 19-40.

Taviani M., Remia A., Esu D. and Sami M., Messinian lago-Mare mollusc fauna from the Gorgona island slope, Tyrrhenian Sea, Geobios 40, 2007, 351-358.

Thinon I., Réhault J.P. and Guennoc P., East-Corsica basin, In: Lofi J., Déverchère J., Gaullier V., Gillet H., Gorini C., Guennoc P., Loncke L., Maillard A., Sage F. and Thinon I., (Eds.), Seismic Atlas of the "Messinian Salinity Crisis" Markers in the Mediterranean and Black Seas. Commission for the Geological Map of the World and Memoires de la Société Géologique de France, Nouvelle Série, 2011, $43-45$.

Viaris de Lesegno L., Etude structurale de la Mer Tyrrhénienne septentrionale, Thèse de 3ème cycle. Paris VI., 1978, 1-170.

Viaris de Lesegno L., Gennesseaux M. and Réhault J.P., La tectonique néogène et les séries sédimentaires dans le bassin Nord-Tyrrhénien, Revue Géogr. Phys. Géol. Dyn. 2 (XX), 1978, 20-42.

Westerman D.S., Dini A., Innocenti F. and Rocchi S., Rise and fall of a nested Christmas-tree laccolith complex, Elba Island, Italy, In: Breitkreuz C. and Petford N., (Eds.), Physical Geology of Highlevel Magmatic Systems, 2004, Geological Society; London, 195-213, Special Publications ed. The Geological Society of London.

Zarki-Jakni B., van der Beek P., Poupeau G., Sosson M., Labrin E., Rossi P. and Ferrandini J., Cenozoic denudation of Corsica in response to Ligurian and Tyrrhenian extension: results from apatite fission track thermochronology, Tectonics 23, 2004, TC1003.

Zitellini N., Trincardi F., Marani M. and Fabbri A., Neogene tectonics of the northern Tyrrhenian Sea, G. Geol. 48 (1), 1986, 2.

\section{Figure Captions}


Fig. 1: a) Map showing distribution of MSC units in the Western Mediterranean at present-day (modified from Lofi et al., 2011). B) Location of the study area (red box) on the Late Messinian paleogeographic and paleotectonic map of Jolivet et al. (2006).

Fig. 2: Bathymetric maps [isobaths: $100 \mathrm{~m}$ (solid line) or $20 \mathrm{~m}$ (dashed line)] of (a) the Northern Tyrrhenian Sea; (b) the Corsica Basin. The Corsica Basin is divided into two sub-basins, the Golo Basin to the North and the Orbo Basin to the South. IR: Île-Rousse, C: Corte, S: Solenzara, AB: Neogene Aleria Plain, BP: Bastia Plain, SF: Saint-Florent Basin; Go: Gorgona Island, Gi: Giglio Island, Ba: Baronie Seamount, E: Etruschi Seamount, C: Cialdi Seamount, V: Vercelli Seamount, B: Bastia, A: Aléria, Bo: Bonifacio, Star (Ca): Caprera Seamount. Dashed line: detachment fault named 41st parallel zone (Spadini and Wezel, 1994). Bathymetric data compilation: BRGM; data sources: SHOM, IFREMER, University of Paris VI.

Fig. 3: Simplified transect across eastern Corsica-Northern Apennines showing the proposed structural-stratigraphic setting of the Corsica Basin in the Middle Miocene (not to scale, modified from Cornamusini and Pascucci, 2014). Note that the EPR is not yet well developed and the marine depositional environments of the proto-Corsica Basin seem to correspond to shelf or shallow sea.

Fig. 4: Synthetic logs of the Neogene infilling of (a) the Neogene Aleria Plain (Loÿe-Pilot and Ferrandini, 2014; Serrano et al., 2013) and (b) the EPR (Cornamusini and Pascucci, 2014).

Fig. 5: Locations of existing seismic surveys and geological data. The tectonic structures of the Tuscan Shelf are taken from Carmignani et al. (2004). AP: Neogene Aleria Plain; BP; Bastia Plain; Black triangle: Agip industrial wells (Martina 1 and Mimosa 1); Black circle: Rock samples (BS77-2 and BS78-20) by coring. 
Thinon et al. In press 2016 - Seismic markers of the Messinian Salinity Crisis in an intermediate-depth basin: data for understanding the Neogene evolution of the Corsica Basin (Northern Tyrrhenian Sea) - Marine and Petroleum Geology

Fig. 6: Seismic facies of the "Messinian Fm" (BU) in the Corsica Basin on analogue lowresolution $B C O$ seismic profiles, described and previously referred to as M by Aleria (1979). PQ: Plio-Quaternary unit. The BU unit lies between the seismic unit PQ dated as Plio-Quaternary and the pre-MSC seismic unit correlated with the pre-MSC Miocene deposits.

Fig. 7: Seismic profile (BS97-22; see location on Fig. 8), oriented WNW-ESE, showing the sedimentary filling and incision system of the Corsica Basin, as well as markers of the $\mathrm{MSC}\left(\mathrm{BU}_{1}\right.$ unit, $\mathrm{BU}_{2}$ unit, MES, TES, BES and IES). At the edges of the basin, the TES and IES join up with the BES to form a single surface, the MES. The box is presented in Fig. 15.

Fig. 8: Pre-Pliocene geological Map at 1:250,000 scale showing the distribution of formations cropping out beneath the Plio-Quaternary cover of the margin and Corsica Basin. AP: Neogene Aleria Plain; BP; Bastia Plain. The isochrons of the depth of the MES and of the TES, corresponding to the base of the Plio-Quaternary unit, are also represented on this map. The Plio-Quaternary formations are not shown. Bold solid lines represent the seismic line traces presented in this study.

Fig. 9: Isopach map (time in twtt (ms)) of the (a) $\mathrm{BU}_{1}$ unit and (b) the $\mathrm{BU}_{2}$ unit, built from the 3D geological model (Calcagno et al., 2004), showing in particular the thickness of these units in the Orbo basin. The depositional depocentre migrated westwards between the deposition of $\mathrm{BU}_{1}$ and $\mathrm{BU}_{2}$. The incised paleovalley network and main tectonic structures are shown on the map. The southern limit of the $\mathrm{BU}_{1}$ and $\mathrm{BU}_{2}$ units coincides with the main tectonic structures: the Solenzara Fault and the Caprera fault. The other main tectonic structures, such as the StAntoine and Scoglio d'Affrica faults, seem to delimit minor depositional depocentres. AP: Neogene Aleria Plain.

Fig. 10: Isopach maps of the Plio-Quaternary unit derived from the 3D geological model (Calcagno et al., 2004). Map a: the whole Corsica Basin; the main depocentre is located in the 
Thinon et al. In press 2016 - Seismic markers of the Messinian Salinity Crisis in an intermediate-depth basin: data for understanding the Neogene evolution of the Corsica Basin (Northern Tyrrhenian Sea) - Marine and Petroleum Geology

Golo Basin; minimum thicknesses are located on the EPR, on the upper continental slope and on the shelf of the East-Corsica margin, except in front of the Bastia Plain . Map b: Detail of the Orbo Basin (MNT grid $=50 \mathrm{~m}$ ). The $\mathrm{PQ}$ infilling highlights the complex incised paleovalley network which cut the syn- and pre-MSC formations. The Caprera Canyon, oriented NE-SW, flows into the North Tyrrhenian basin, south of the Caprera seamount. The East-Corsica paleovalley network appears to be interrupted by the Caprera seamount. The western channel system seems to connect into the onshore fluvial systems of East Corsica.

Fig. 11: Seismic cross-sections (see location on Fig. 8) showing the Margin Erosion Surface (MES): (a) across the narrow North-East Corsica margin (Co01bf107 line). Note the occurrence of chaotic bodies on the MES at the foot of the continental slope off Cap Corse; (b) across the Aleria continental shelf (L187 line). Note the occurrence of major incised valleys filled by PlioQuaternary deposits. The pre-MSC unit is faulted. PQ: Pliocene- Quaternary unit. Q: Quaternary unit.

Fig. 12: Seismic profiles (see location on Fig. 8) across (a) the North-East Corsica continental shelf and (b) northern edge of the Golo Basin (HR02D314 line), showing deformation of the thick PQ sedimentary cover (HR02D315-312 line). The faults with a normal component affect the preMSC basement. Some of these faults affect the PQ unit with a reverse component.

Fig. 13: Seismic cross-section (BS97-13; see location on Fig. 8) showing erosive character of the BES and IES. The erosive character of IES is picked out by the presence of small gully-type incisions. The BES highlights weak topographic relief covered by the onlapping $\mathrm{BU}_{1}$ unit. The $\mathrm{BU}_{2}$ unit, which onlaps onto the IES, contains three major sub-units ( $\mathrm{a}, \mathrm{b}$ and $\mathrm{c}$ ). Minor faults affect the PQ cover directly beneath the N-S incised valley system.

Fig. 14: HR seismic cross-section (BS97-10; see location on Fig. 8) illustrating channel system (V2) following a NNE-SSW axis, and stratigraphic architecture of the Plio-Quaternary unit. 
Thinon et al. In press 2016 - Seismic markers of the Messinian Salinity Crisis in an intermediate-depth basin: data for understanding the Neogene evolution of the Corsica Basin (Northern Tyrrhenian Sea) - Marine and Petroleum Geology

Fig. 15: Seismic cross-section (BS97-22, Fig. 8), oriented WNW-ESE, showing relationships between the Messinian remarkable surfaces (TES, IES, BES and MES) at the western edge of the Corsica Basin at the foot of the Eastern Corsica continental slope. Basinward, the MES divides into three distinct unconformities (BES, TES and IES). $\mathrm{BU}_{1}$ onlaps onto the $\mathrm{BES}$ at the edges of the Corsica Basin. Unit $P Q$ exhibits many internal unconformities. V2 is the westernmost channel system of the East-Corsica incised paleovalley network.

Fig. 16: HR seismic cross-sections (see location on Fig. 8). (a) BS98-34; (b) BS97-03; (c) BS98$42 \mathrm{~b}$, showing details of the MSC markers $\left(\mathrm{BU}_{1}\right.$ unit, $\mathrm{BU}_{2}$ unit, MES, TES, BES and IES) and morphology of the N-S-trending valley (V1, Fig. 18) from north (a) to south (c). Note that the width and depth of the valley increase from North to South. Note also that the flanks of the valley display small terraces suggesting a change/stagnation during the incision. Within the $\mathrm{P}$ unit, several disconformities are observed in the axis of the valley. P: Lower Pliocene; PQ: Plioquaternary.

Fig. 17: A HR seismic cross-section (BS99-54; see location on Fig. 8) oriented E-W, across the south end of the Corsica Basin incised paleovalley network (V3). The incised valley (V3, Fig. 18) is obstructed by a structural high, called here the Caprera Seamount. This structural high is bounded by the Caprera Fault. The PQ formation is affected by deformation. P: Lower Pliocene; PQ: Pliocene-Quaternary; S: undifferentiated basement.

Fig. 18: (a) Map of the incised paleovalley network in the Corsica Basin with, in the northern part, the N-S-trending valley to the east (V1) and the channel system (V2) to the west. The southern part of the network is characterized by a single wide and deep valley (V3). Minor incisions are observed: on the North-Sardinian margin (Caprera Canyon), on the Bonifacio slope (Bo), in the prolongation of the main canyons of the Neogene Aleria Plain (Vc). M: mouth of the incision system of the Corsica basin. The location of the seismic lines is indicated. (b) Depth 
profile (twtt (s)) of the base of the N-S-trending valley axis (dashed line in box a) from north to south along the EPR. The equilibrium profile of the N-S-trending valley is disturbed. A relative uplift of at least $110 \mathrm{~m}$ is observed in the north and south.

Fig. 19: Interpreted synthetic cross-section of the MSC units and erosion surfaces of the Corsica Basin (this study), correlated with the deposition sequence of the deep Mediterranean basins (simplified from Gorini et al., 2015). The junction between the TES and BES is at a depth of 1.4 twtt (s) (black dot) and the junction between the reflooding and MES in the deep Tyrrhenian basin is at 2.5 twtt (s). pre-MSC= pre-MSC Miocene formations. MLM: Messinian upper megasequence (from Gorini et al., 2015), not yet observed in the deep Tyrrhenian basins. MUM: Messinian upper megasequence (from Gorini et al., 2015).

Fig. 20: Sketch illustrating Neogene evolution of the Corsica Basin. The points A - G refer to the stages of development explained in section 5.6. of the text. 


\section{Figure captions}

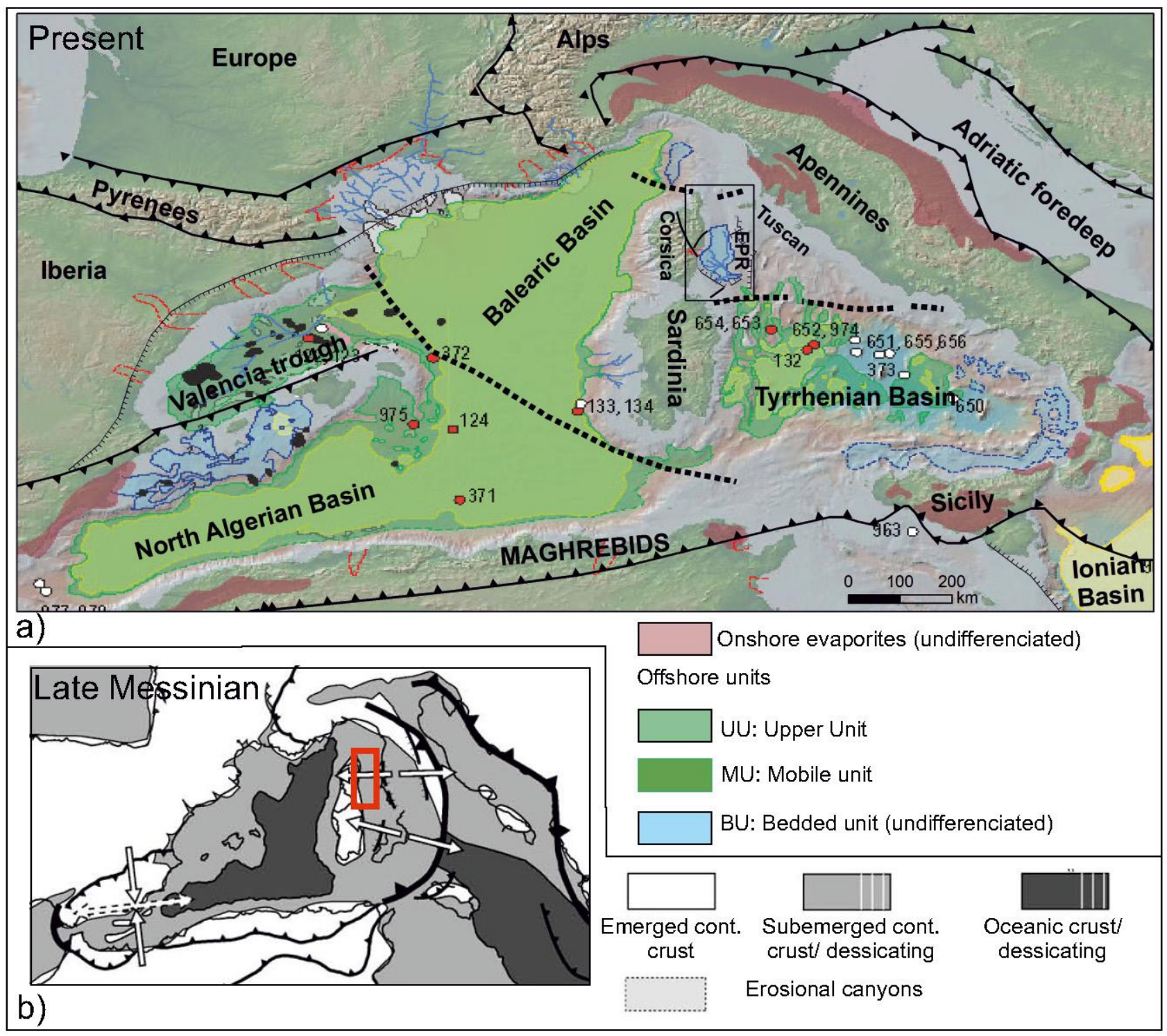

Figure 1 


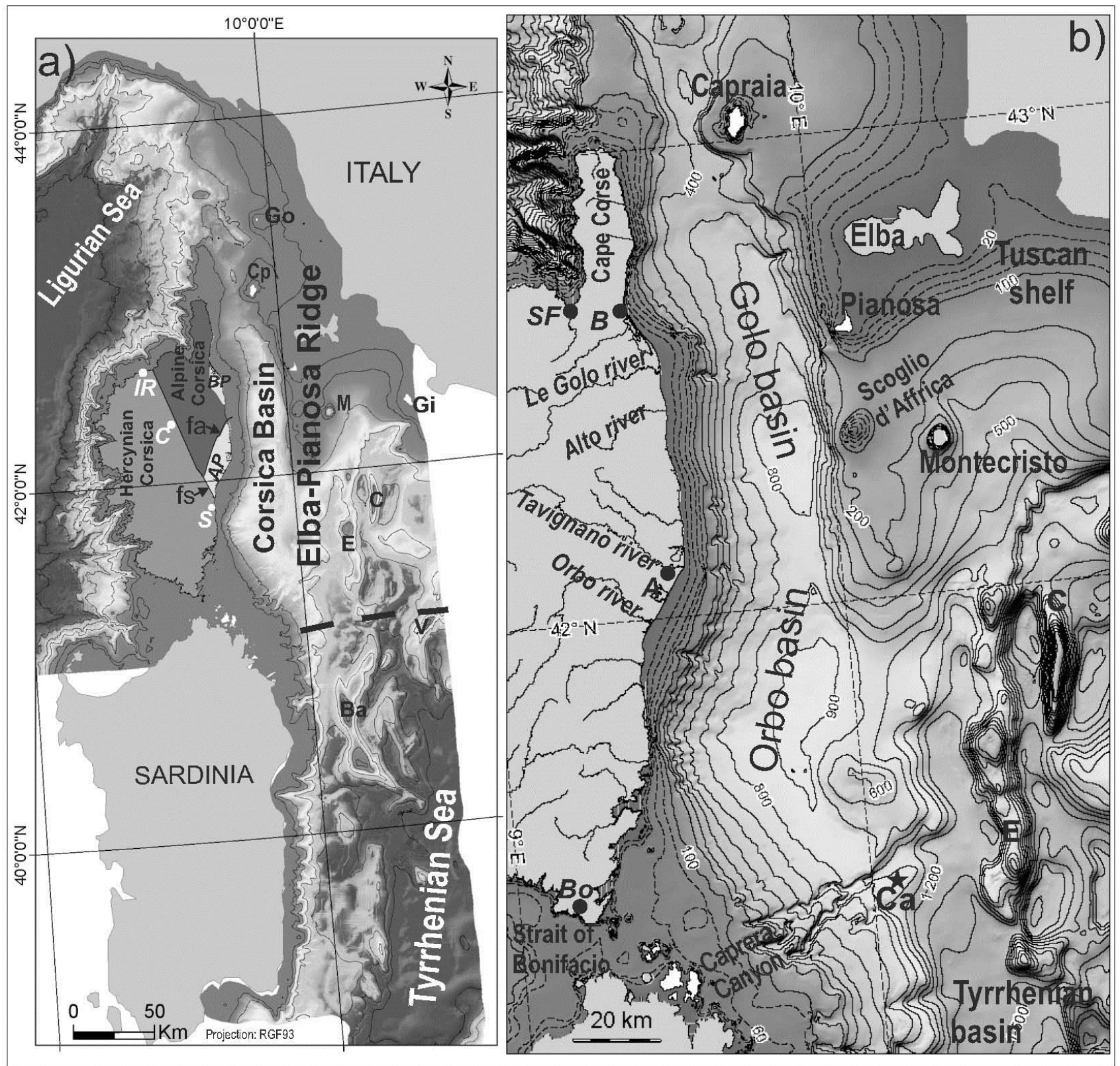

Figure 2 


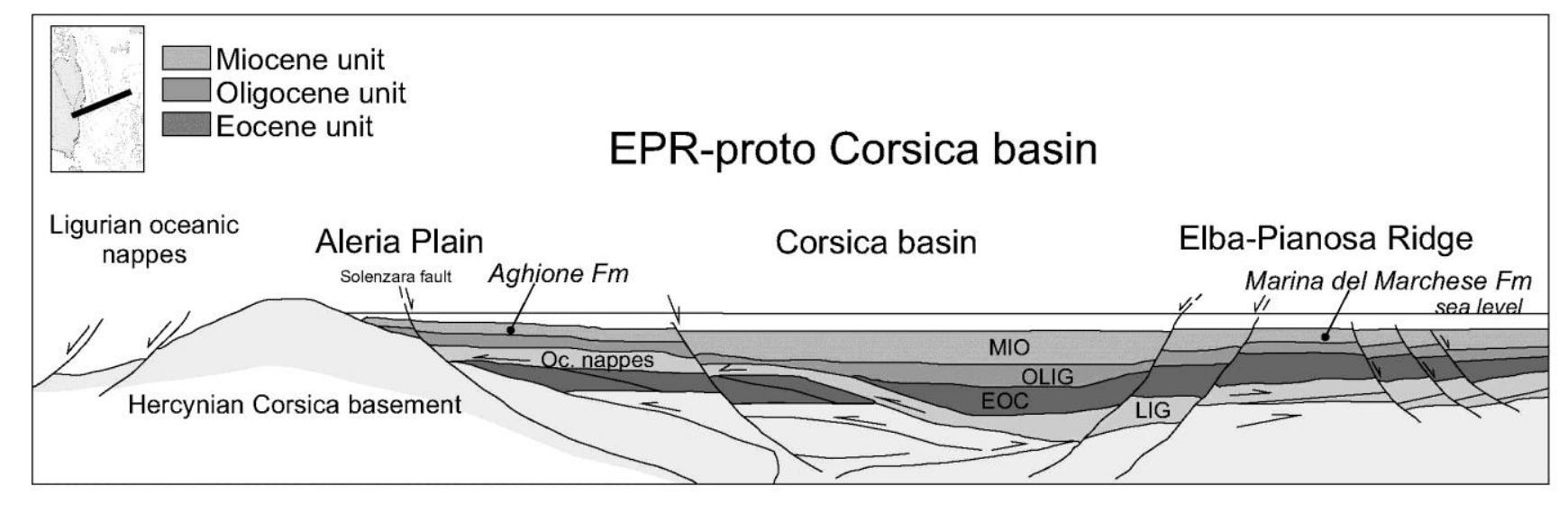

Figure 3 


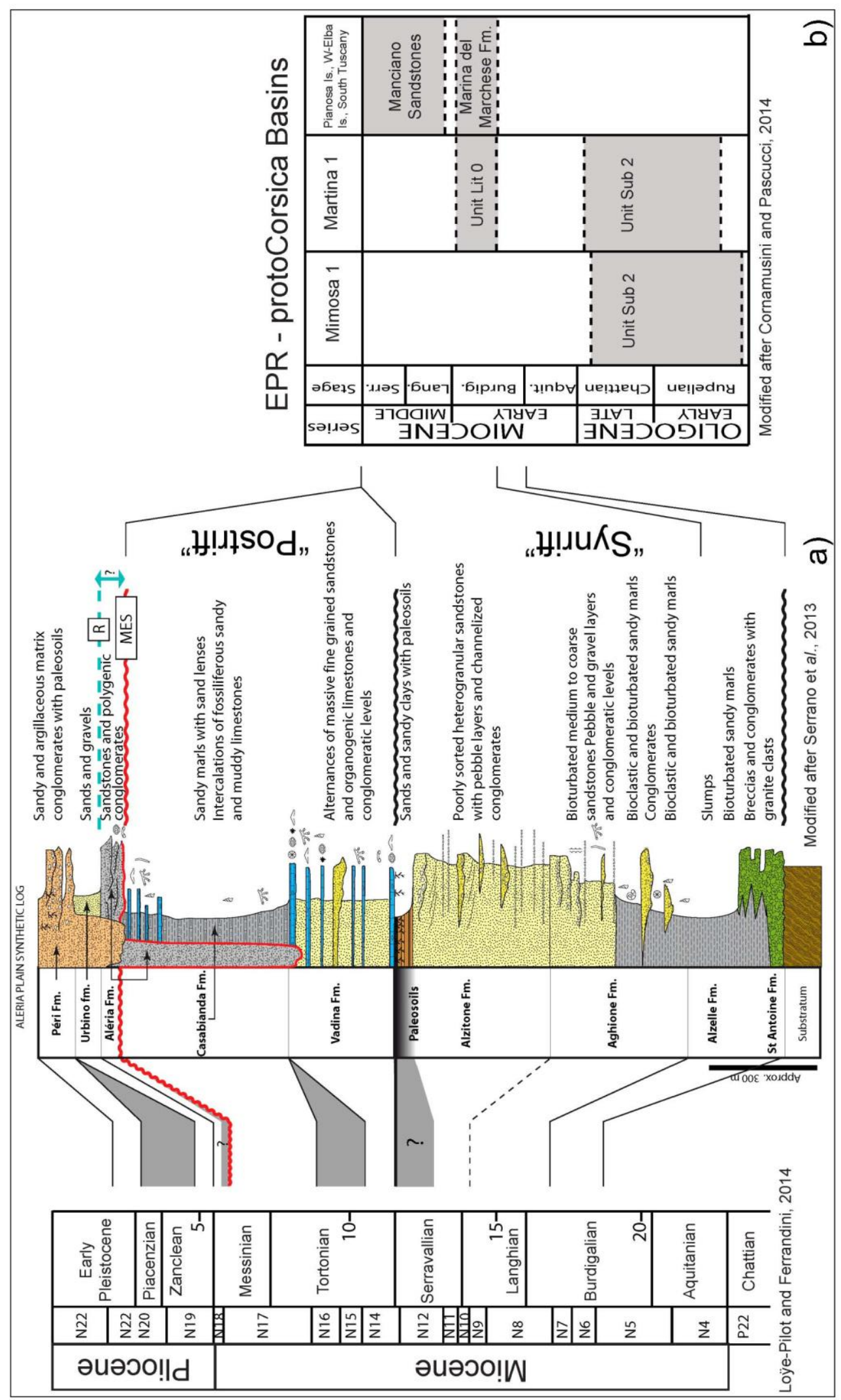

Figure 4 


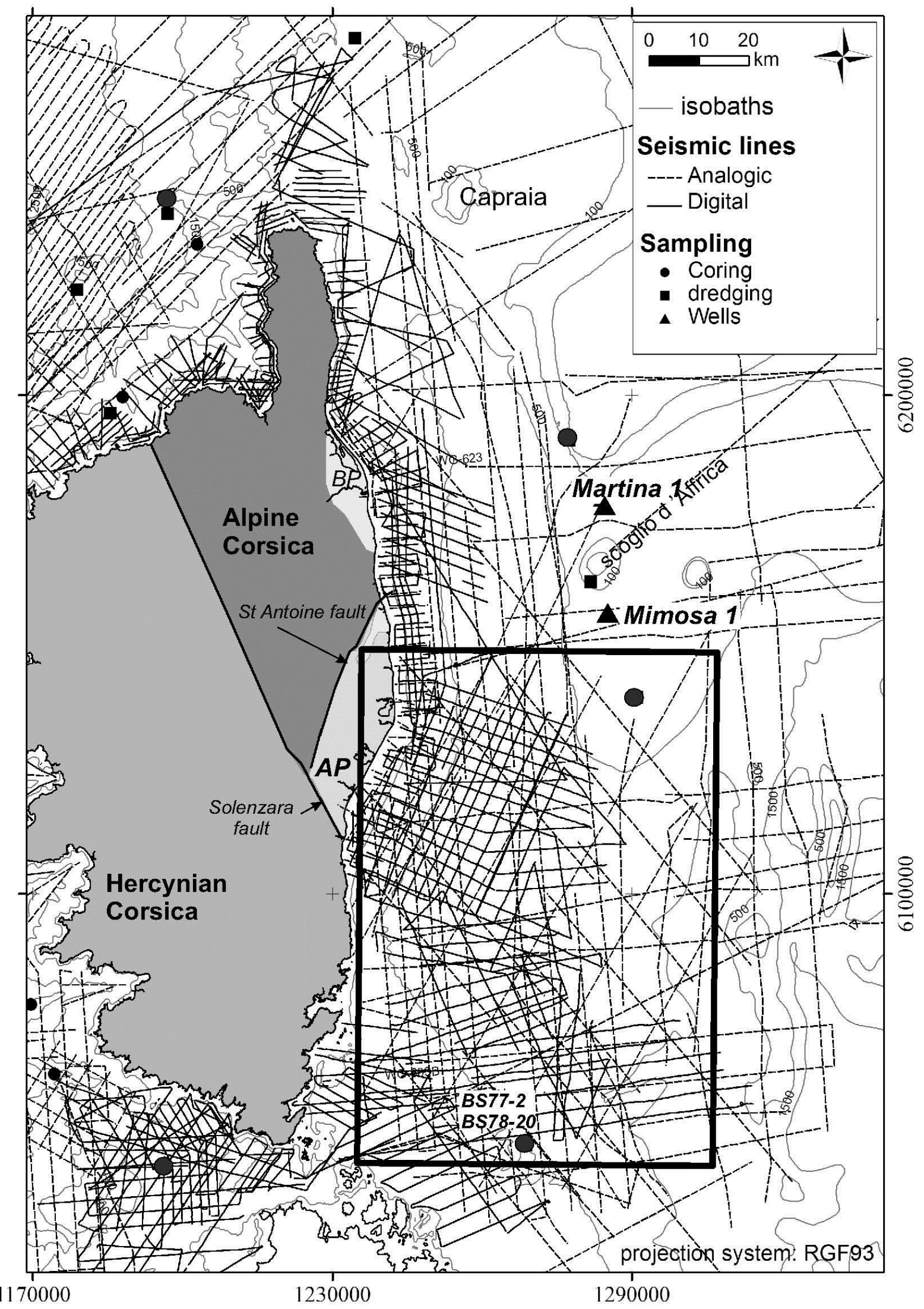

Figure 5 
Thinon et al. In press 2016 - Seismic markers of the Messinian Salinity Crisis in an intermediate-depth basin: data for understanding the Neogene evolution of the Corsica Basin (Northern Tyrrhenian Sea) - Marine and Petroleum Geology

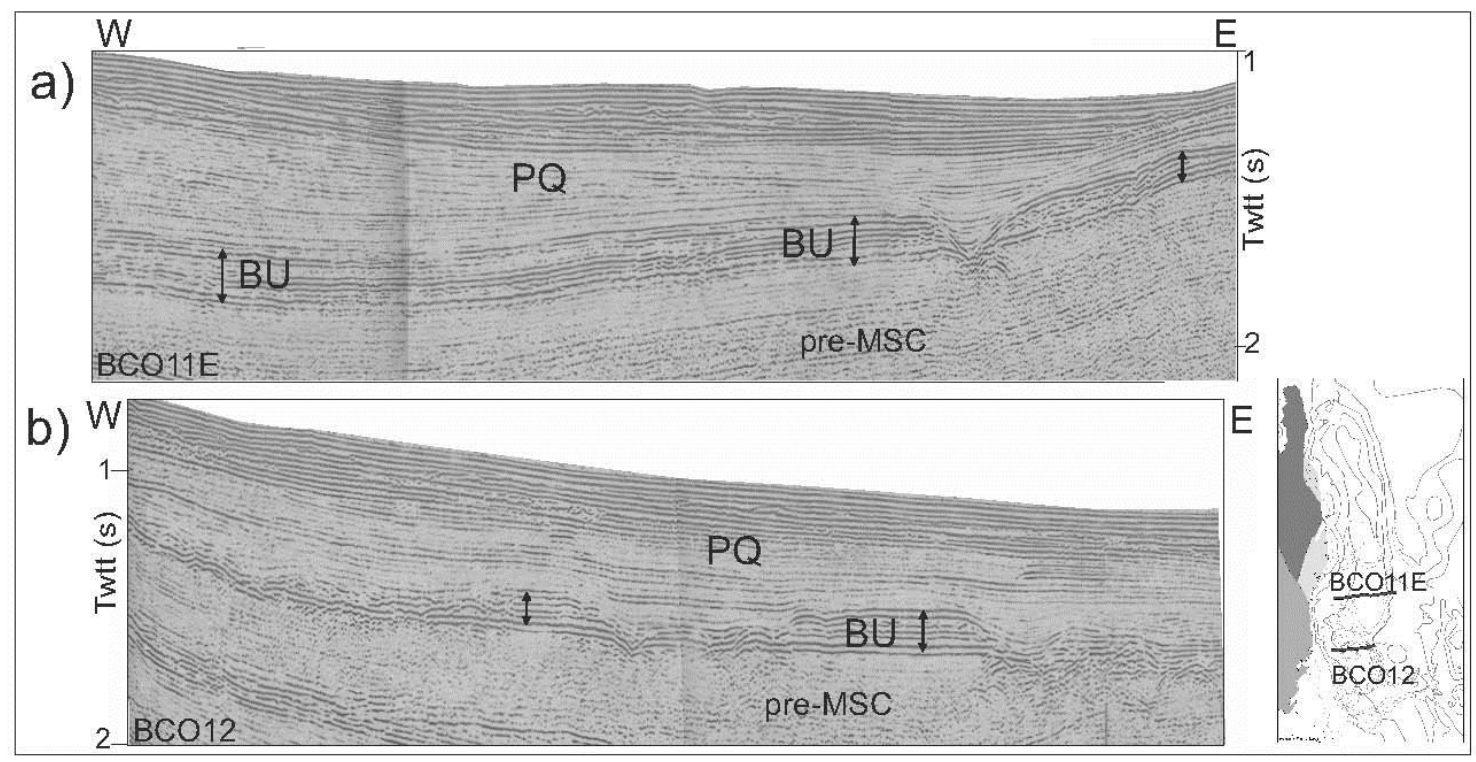

Figure 6 
Thinon et al. In press 2016 - Seismic markers of the Messinian Salinity Crisis in an intermediate-depth basin: data for understanding the Neogene evolution of the Corsica Basin (Northern Tyrrhenian Sea) - Marine and Petroleum Geology

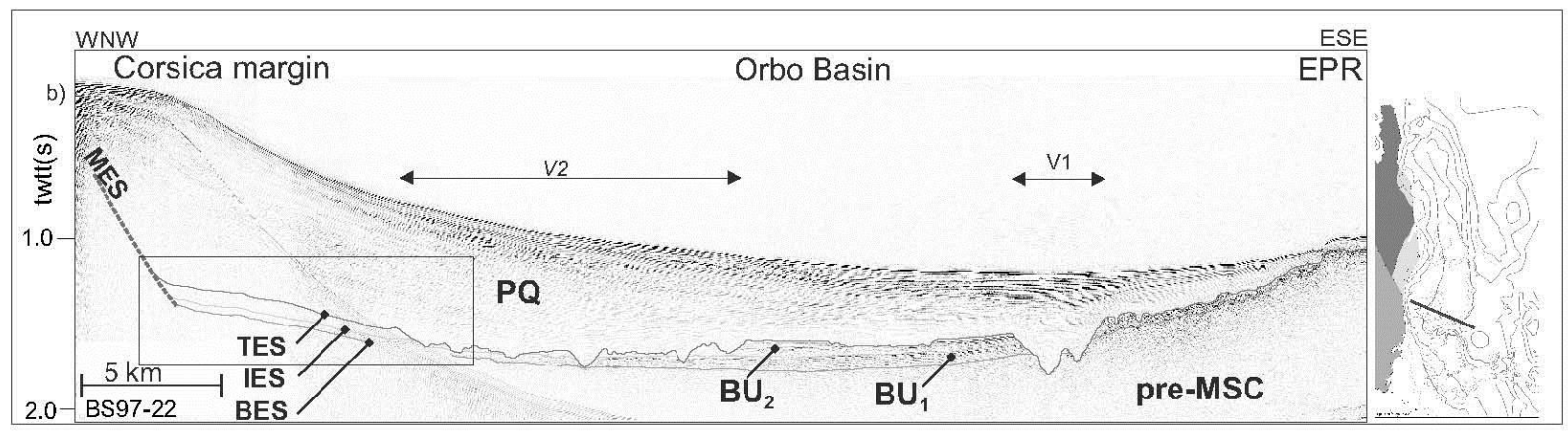

Figure 7 


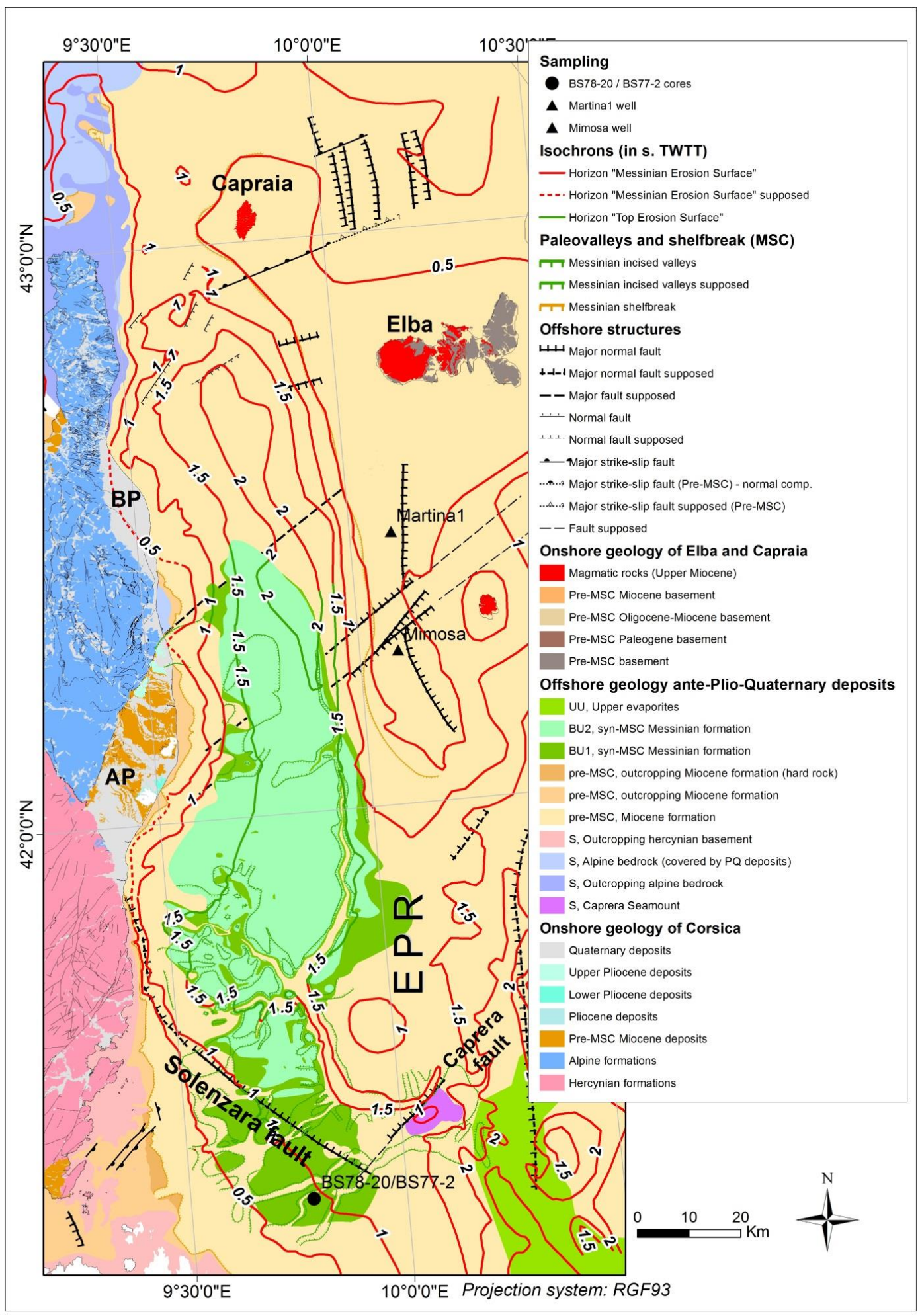

Figure 8 

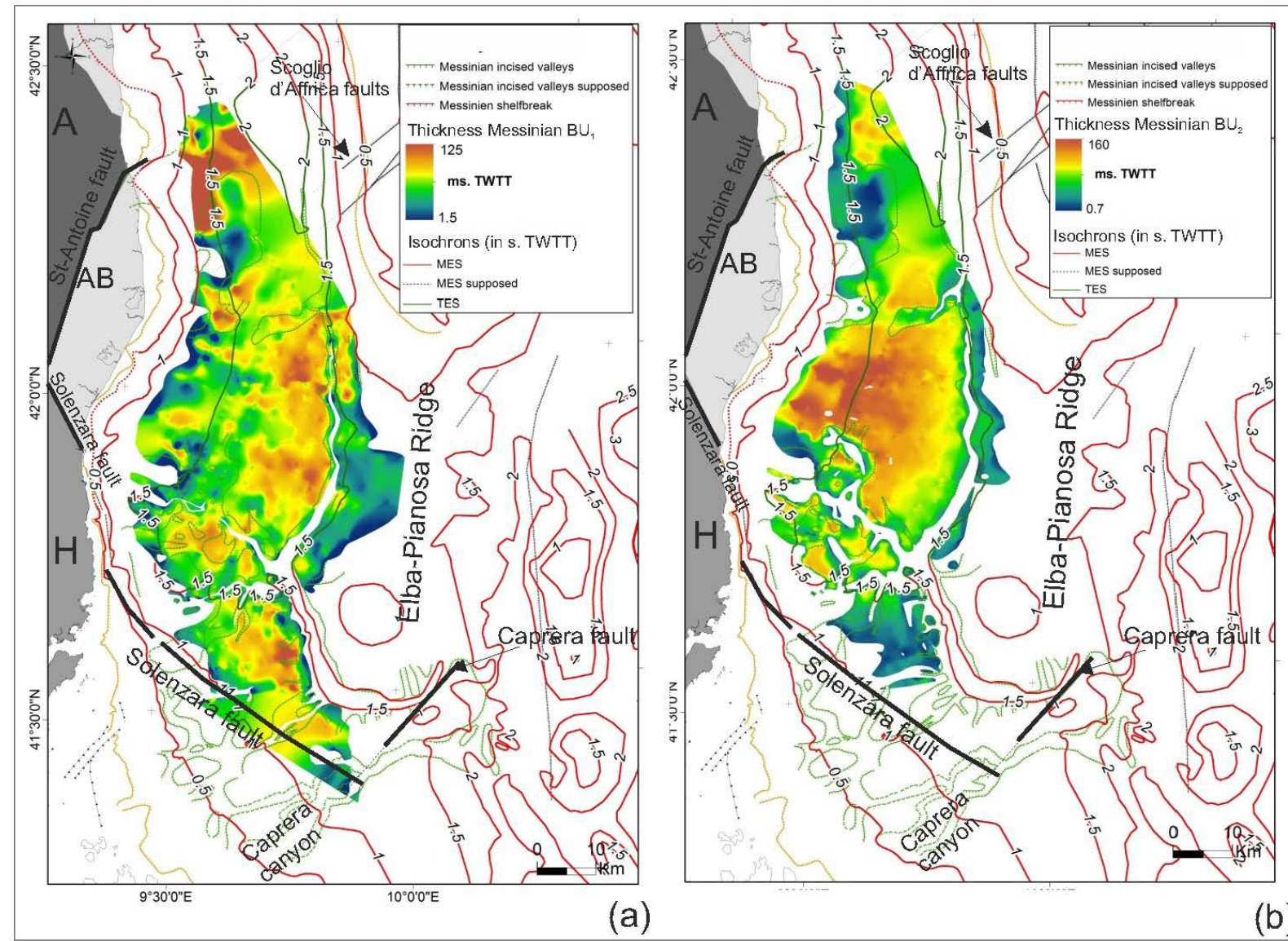

(a)

Figure 9 
Thinon et al. In press 2016 - Seismic markers of the Messinian Salinity Crisis in an intermediate-depth basin: data for understanding the Neogene evolution of the Corsica Basin (Northern Tyrrhenian Sea) - Marine and Petroleum Geology

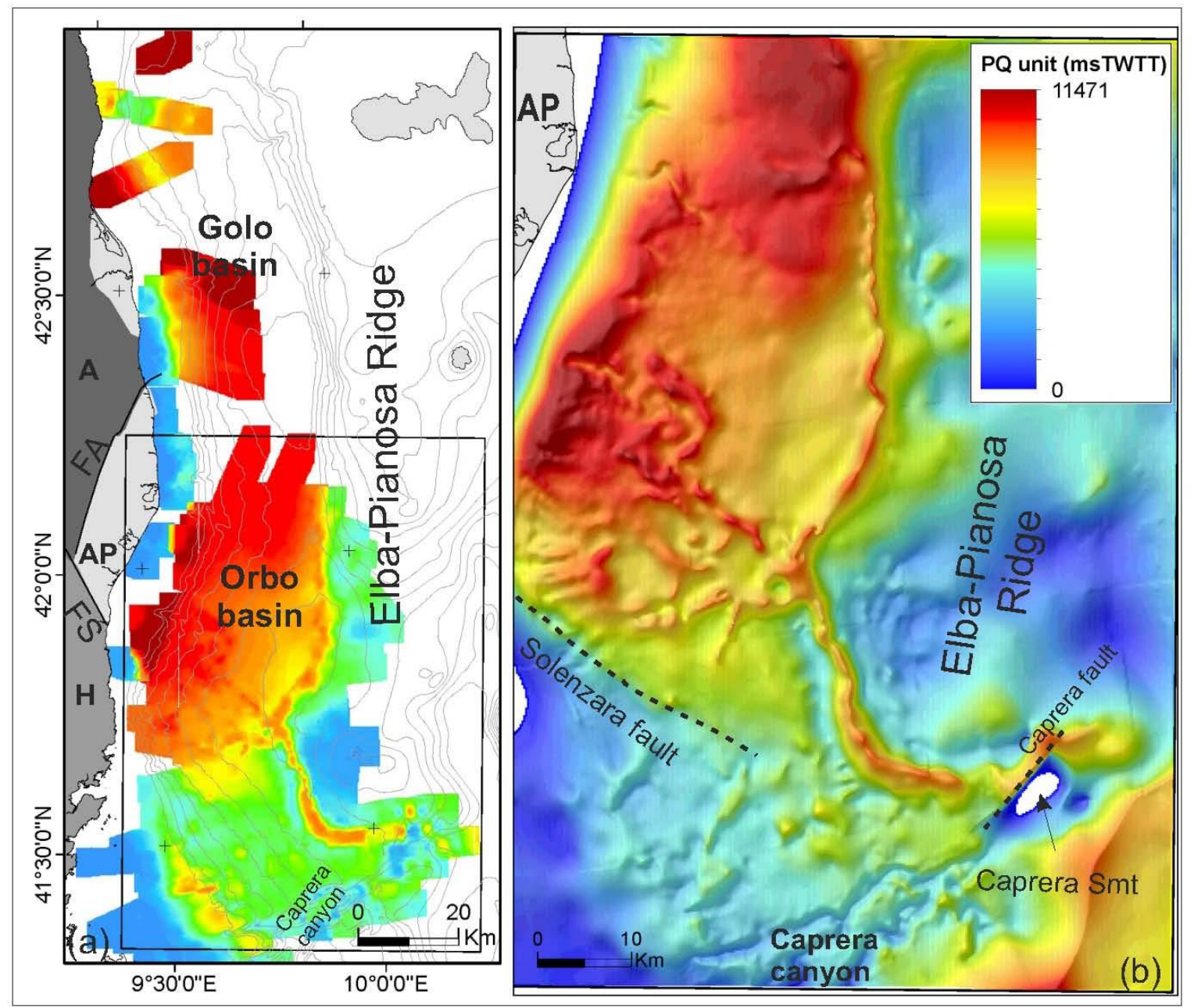

Figure 10 
Thinon et al. In press 2016 - Seismic markers of the Messinian Salinity Crisis in an intermediate-depth basin: data for understanding the Neogene evolution of the Corsica Basin (Northern Tyrrhenian Sea) - Marine and Petroleum Geology

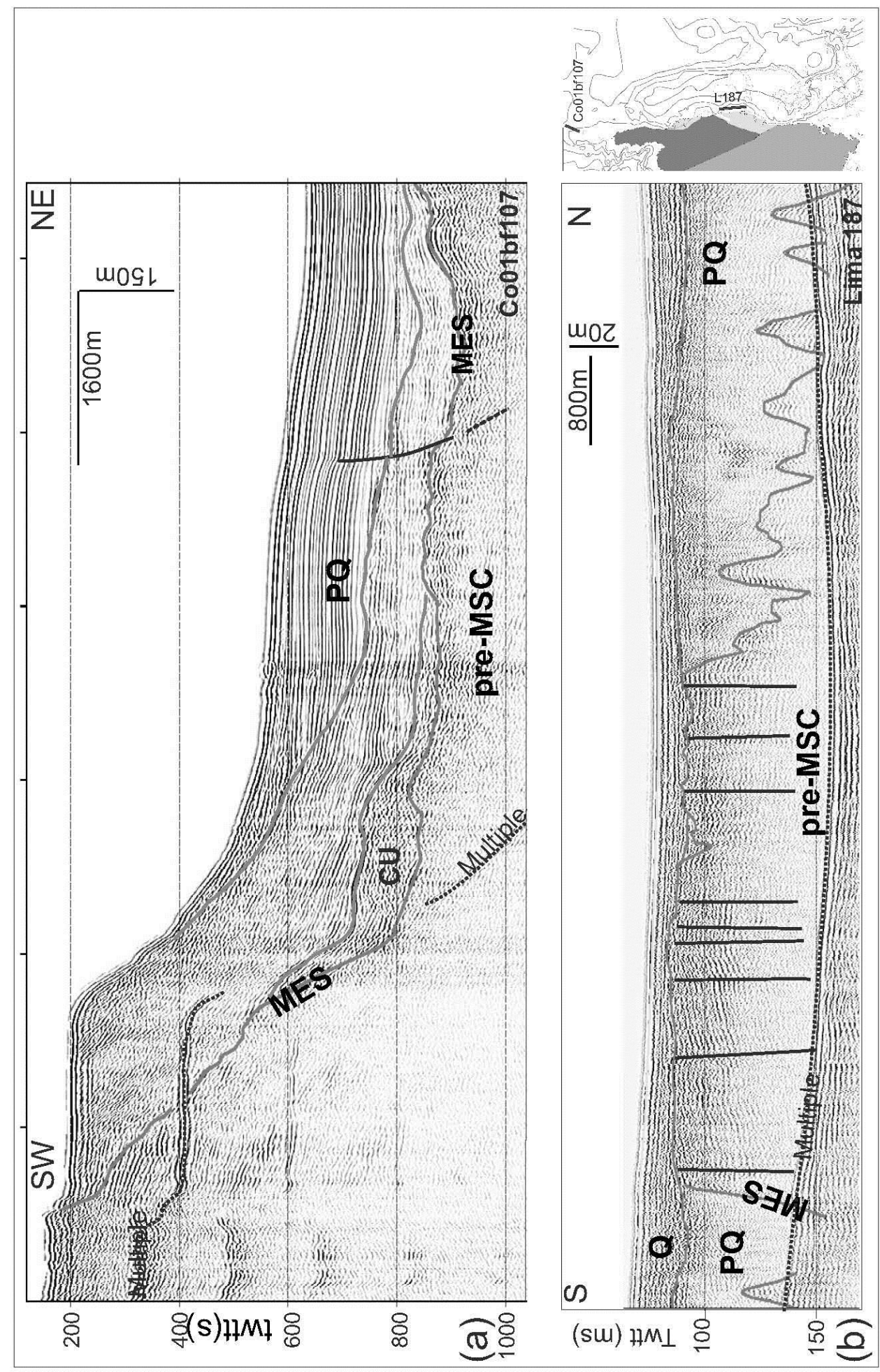

Figure 11 
Thinon et al. In press 2016 - Seismic markers of the Messinian Salinity Crisis in an intermediate-depth basin: data for understanding the Neogene evolution of the Corsica Basin (Northern Tyrrhenian Sea) - Marine and Petroleum Geology

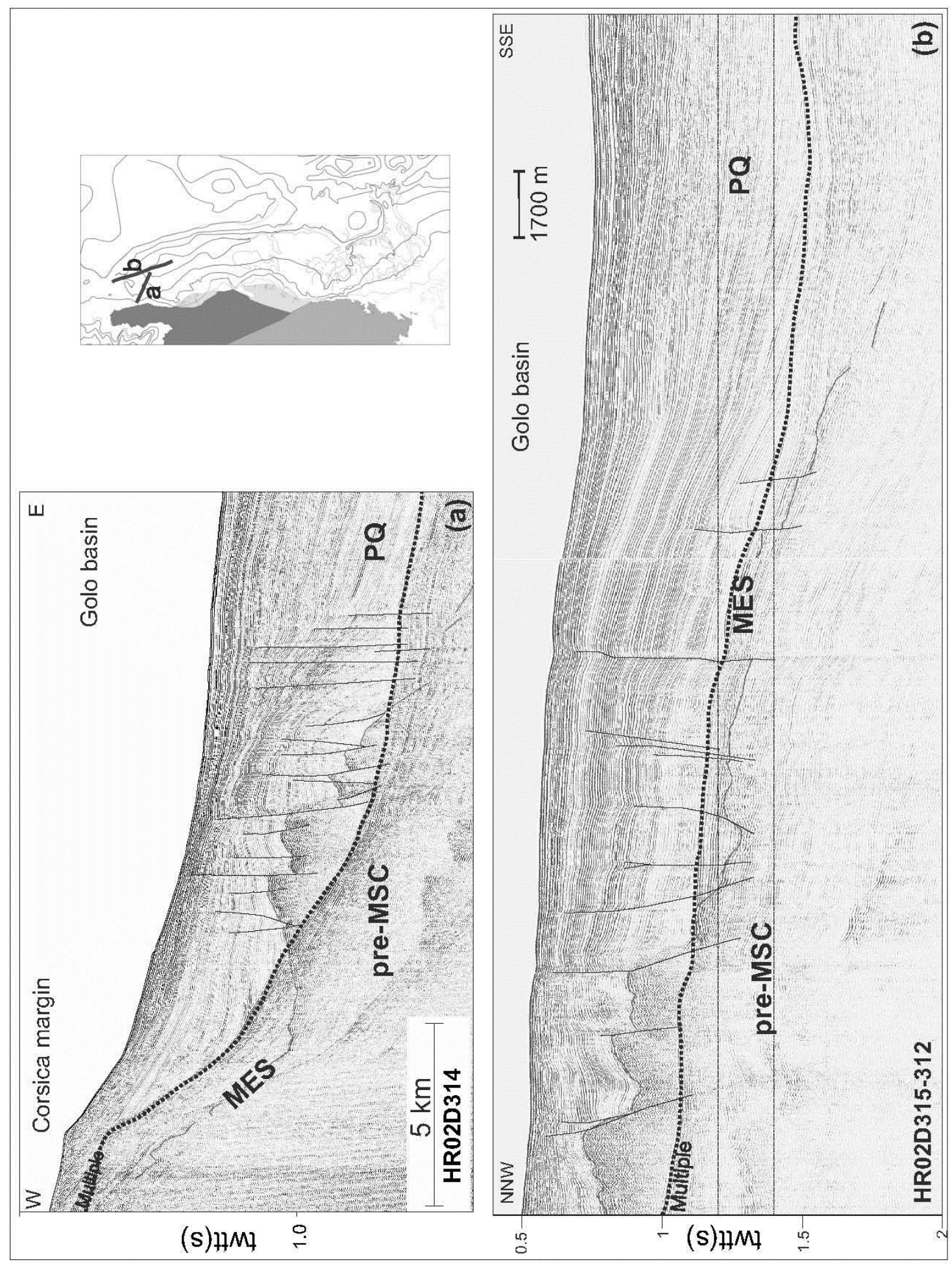

Figure 12 


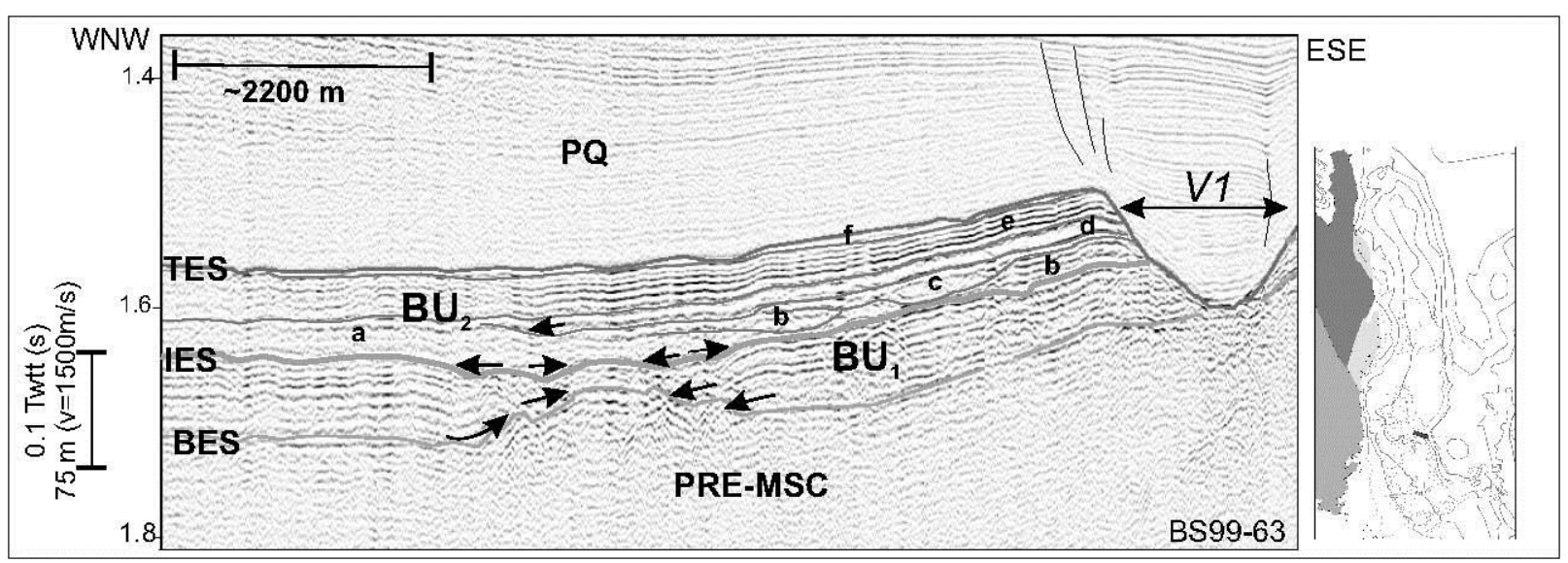

Figure 13

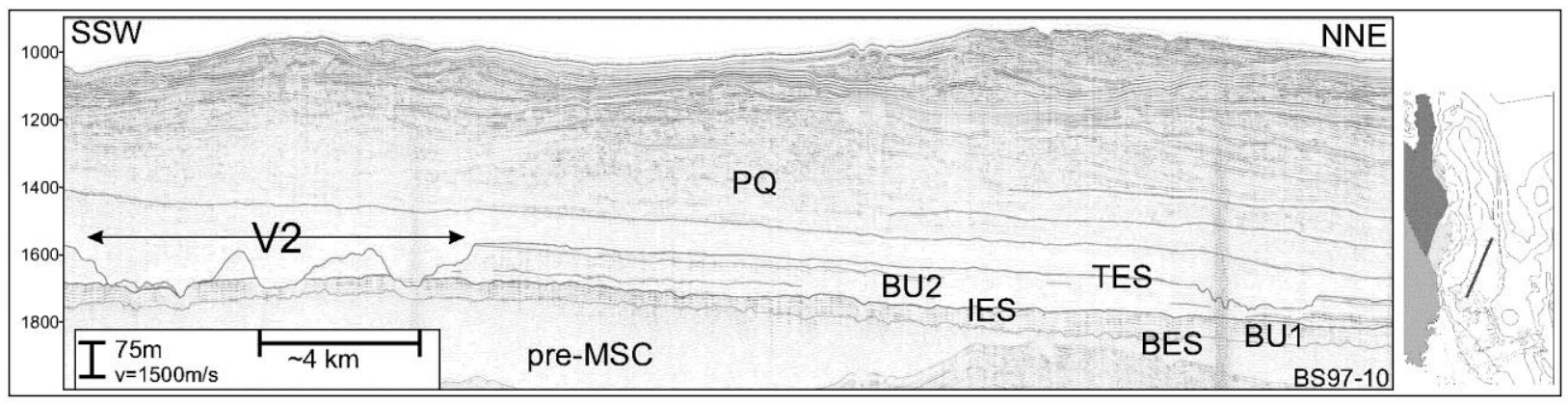

Figure 14

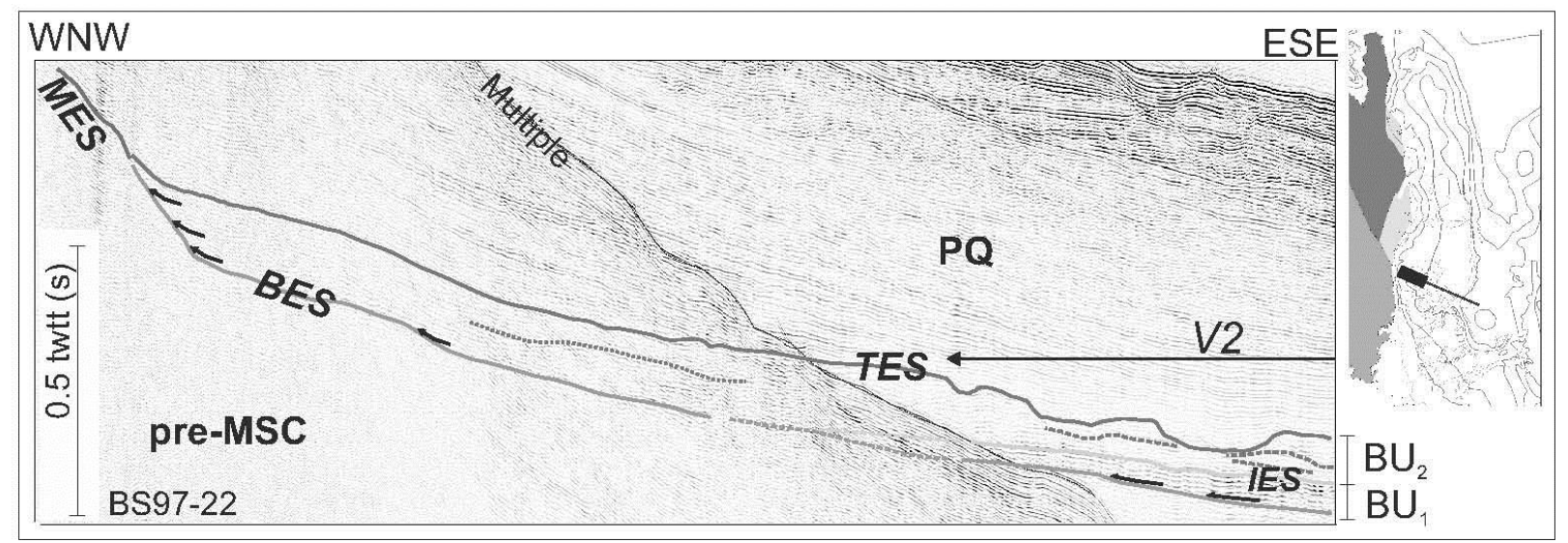

Figure 15 


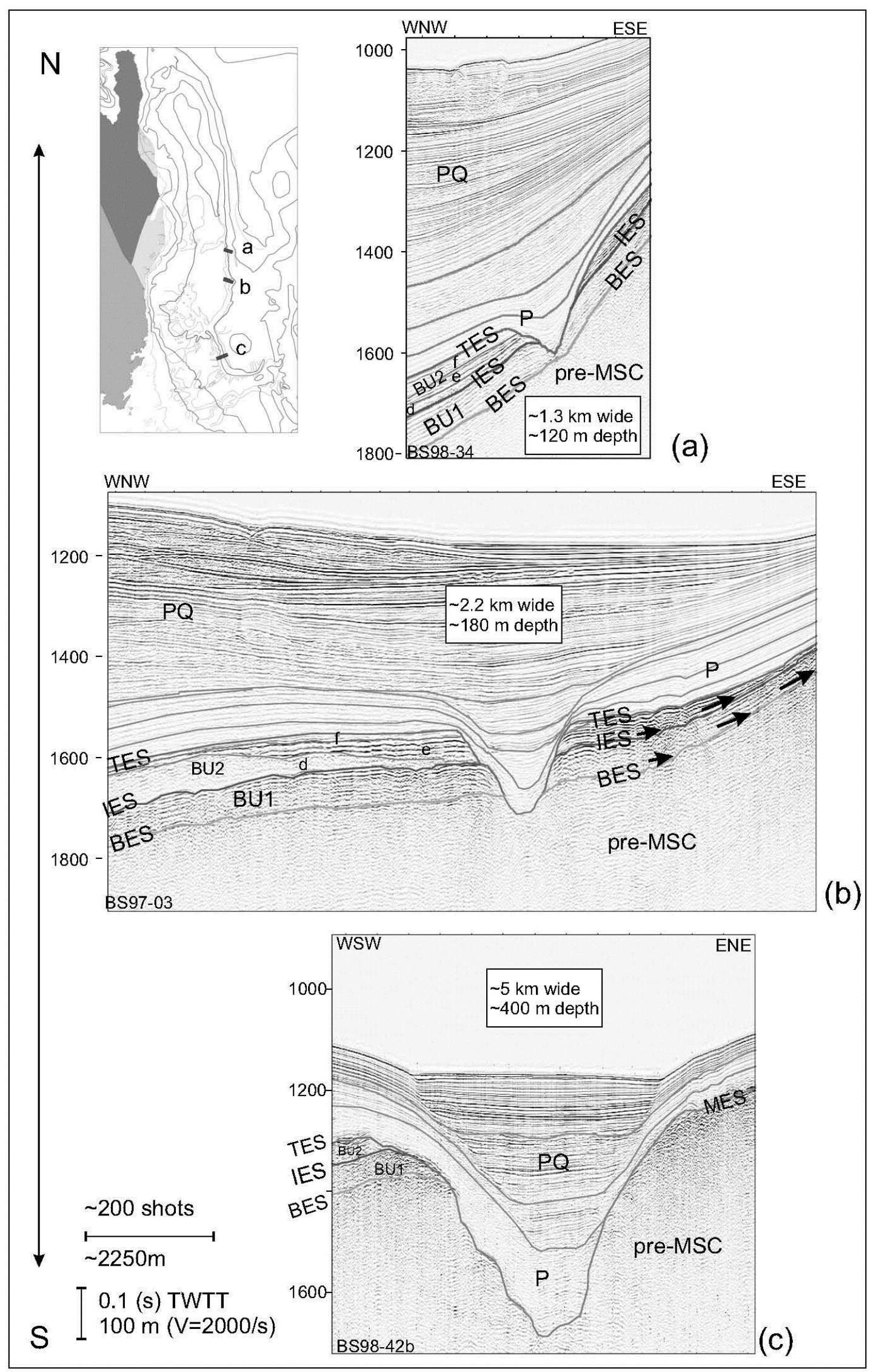

Figure 16 
Thinon et al. In press 2016 - Seismic markers of the Messinian Salinity Crisis in an intermediate-depth basin: data for understanding the Neogene evolution of the Corsica Basin (Northern Tyrrhenian Sea) - Marine and Petroleum Geology

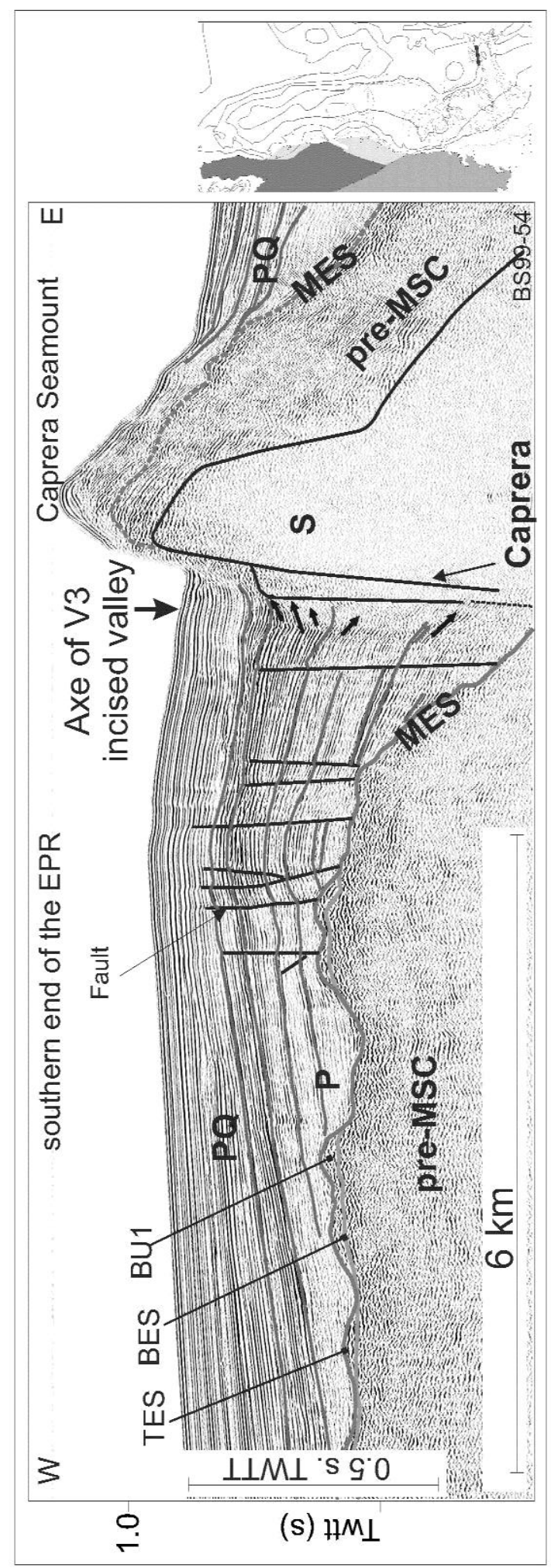

Figure 17 
Thinon et al. In press 2016 - Seismic markers of the Messinian Salinity Crisis in an intermediate-depth basin: data for understanding the Neogene evolution of the Corsica Basin (Northern Tyrrhenian Sea) - Marine and Petroleum Geology

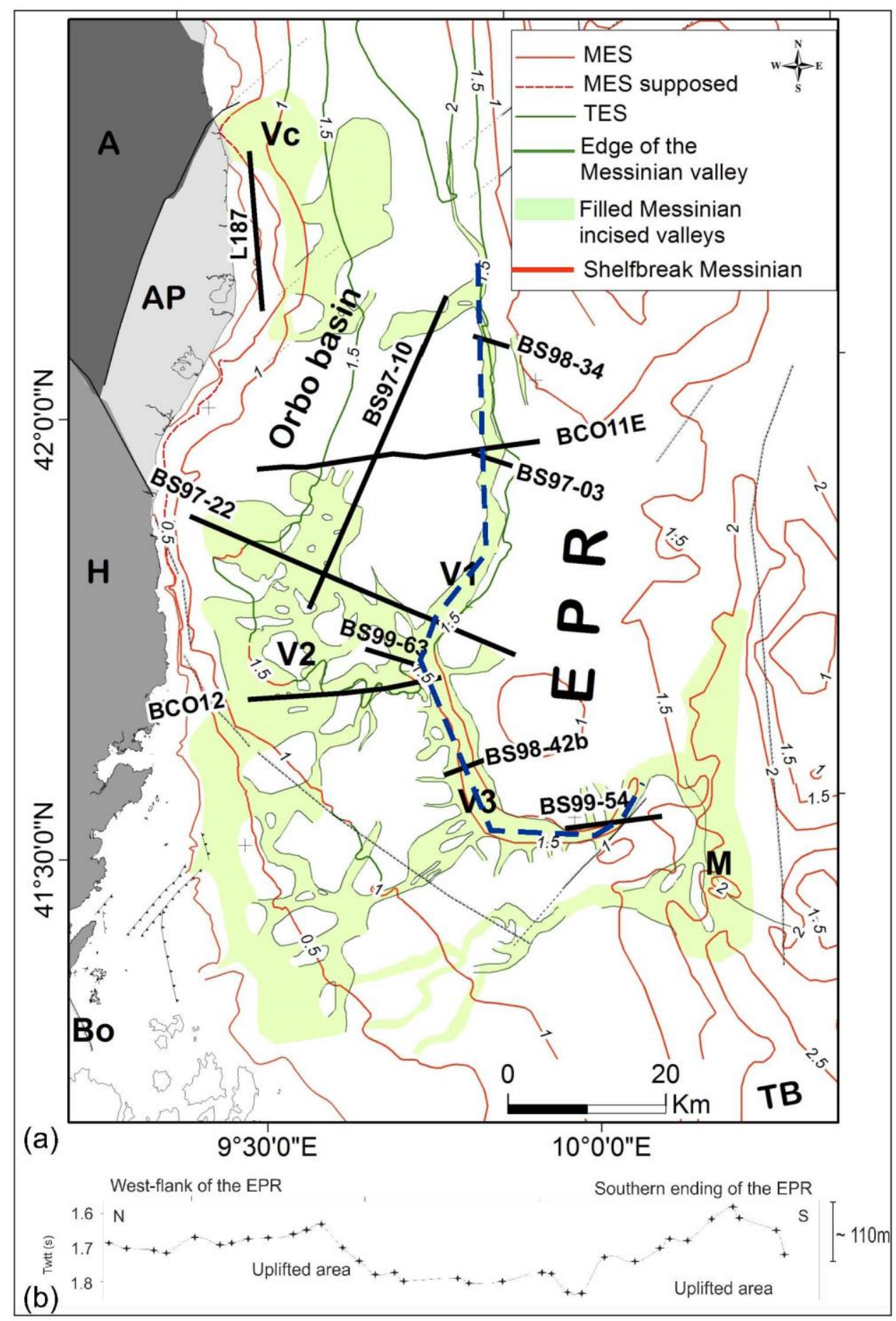

Figure 18 
Thinon et al. In press 2016 - Seismic markers of the Messinian Salinity Crisis in an intermediate-depth basin: data for understanding the Neogene evolution of the Corsica Basin (Northern Tyrrhenian Sea) - Marine and Petroleum Geology

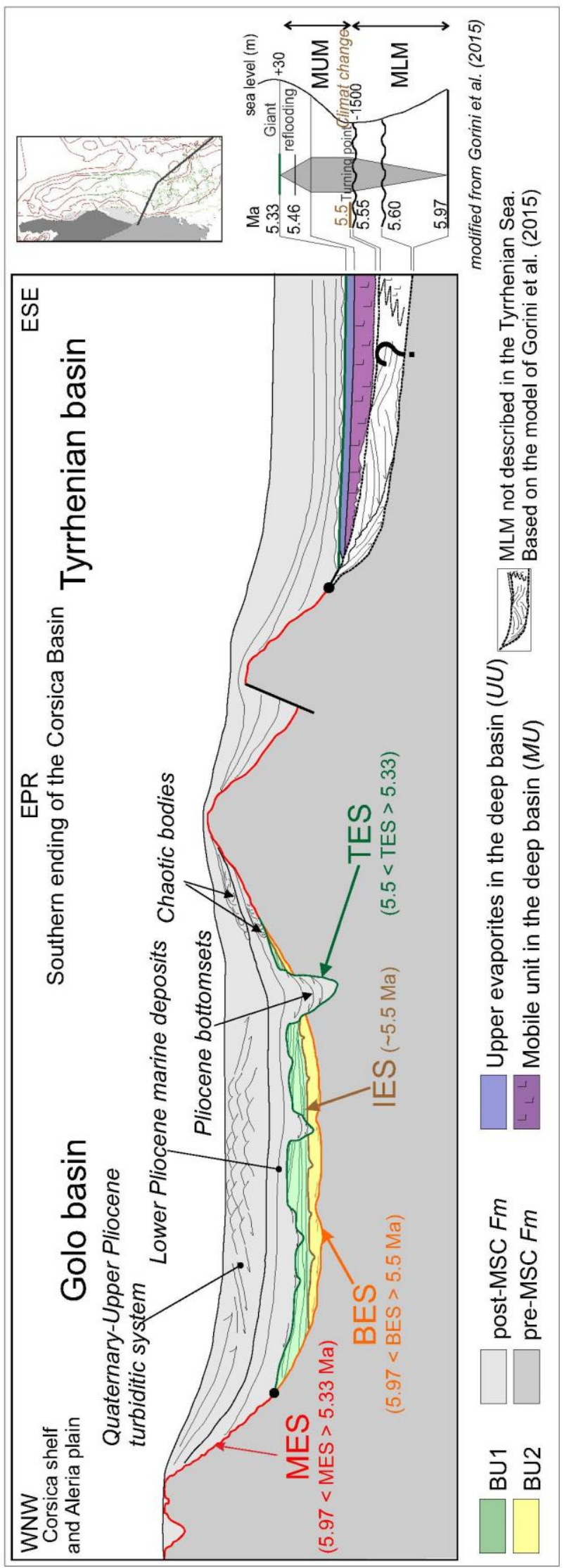

Figure 19 
Thinon et al. In press 2016 - Seismic markers of the Messinian Salinity Crisis in an intermediate-depth basin: data for understanding the Neogene evolution of the Corsica Basin (Northern Tyrrhenian Sea) - Marine and Petroleum Geology

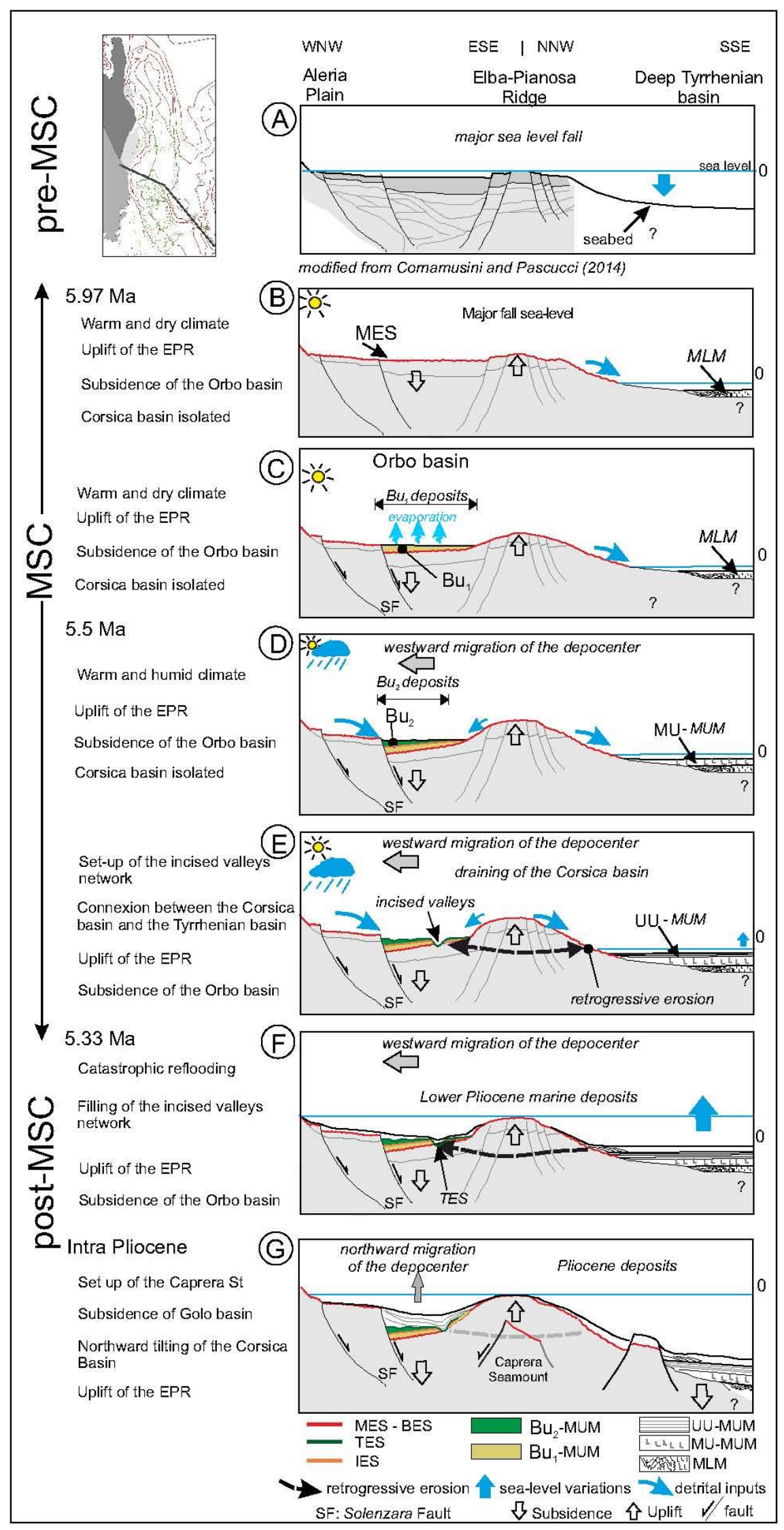

Figure 20 